\title{
Saying it without words: a qualitative study of employee voice in the Iranian building sector
}

\author{
Corresponding author: \\ Professor Ebrahim Soltani \\ School of Business and Quality Management \\ Hamdan Bin Mohammed Smart University (HBMSU), Dubai, UAE \\ e.soltani@hbmsu.ac.ae \\ Co-authors: \\ Dr. Ying Ying Liao \\ School of Business and Quality Management \\ Hamdan Bin Mohammed Smart University (HBMSU), Dubai, UAE \\ Dr. Abdoul Khalegh Gholami \\ Lecturer of Human Resource Management \\ Islamic Azad University \\ Yasuj, Iran \\ Dr. Abdullah Iqbal \\ Senior Lecturer, Kent Business School, \\ University of Kent, Canterbury, Kent, UK
}

Acknowledgment: We would like to extend special acknowledgment to S. Yousefi, N. Yousefi, H. Radar, M. Didekonan and A. Keshavarz for their assistance with this research project. 


\section{Saying it without words: a qualitative study of employee voice in the Iranian building sector}

The primary aim of this study is to examine the nature, extent and workplace experiences of voice in an industry characterized by vulnerable workers with precarious term of employment. Using qualitative data on the practice of voice and participation among a sample of construction and building materials \& products manufacturing firms, we found that the motivation of workers to fulfil their basic human needs take precedence over other needs such as voice and participation intention. The extent to which employee voice was embedded in the organizational policies was found to rely primarily upon the need for compliance with minimum labor legislation and ISO quality management factory regime. Our findings also suggest that voice and participation beyond regulatory and ISO quality compliance remain at the sole discretion of the management that advocated a carrot and stick orientation. The article concludes with the discussion of theoretical and practical implications of the findings and identification of a number of new avenues for future research.

Keywords: precarious employment, employee voice, ISO quality system, case study, construction industry, developing economies

\section{Introduction}

Although prior studies of employee voice have offered a number of important insights into the conceptualization and operationalization of employee voice, a common concern is that there has been a tendency to largely focus on highly prevalent voice arrangements of several Western (Anglo-American) developed economies and a few other newly industrialized nations (see Freeman et al., 2007; Brewster et al., 2007; Mellahi et al., 2010; Wilkinson et al., 2014). Whereas the homogeneity of the employee voice models in the context of Western developed economies is assumed to make fundamental universal assumptions about employer-driven forms of voice and employee attitudes toward voice, recent research evidence (e.g. Wood, 2010; Menendez and Lucio, 2014; Pyman et al., 2017) is said to view such generalization as unhelpful in explaining managerial behavior and employee workplace experiences in the context of (non-Western) developing economies. Wilkinson et al. (2013, p. 268) note that voice and participation rely in the main upon "the context in which schemes are introduced - the competitive situation, management style, employee expectations, and other human resource 
practices as well as on the types of schemes themselves". In a similar vein, Wood (2010, p. 553) observes that while work and employee relations and participation within organizations vary according to organizational profile such as size and type and individual strategic choices by managers or actions and responses by employees, societal and economic context and geographical locale are equally important.

Similarly, the absence of recent empirical evaluations suggests that many studies of employee voice and much of the voice-focused human resource management (HRM) research fail to account for developments in contemporary world of work which has witnessed a trend toward increasing prevalence of precarious work (see Kalleberg, 2009; Burgess et al., 2013). Researchers working within this perspective argue that the academic legitimacy of the notion of employee voice is closely linked to not only voices of mainstream employees but also voices of non-mainstream and precarious workers. In fact, researchers have presented evidence to argue that non-standard workers with atypical contracts and people from ethnic minority communities have been neglected in much of the theoretical framing and organizational interventions on employee voice (see Burgess et al., 2013; Syed, 2014, p. 421). Thus, as Avery et al. (2011) have observed, "employee voice is particularly important for employees with less tenure (see Wilkinson and Fay, 2011, p. 71).

The preceding discussion highlights a need for empirical evaluations that examine contemporary non-Western organizational contexts with precarious employment arrangements in relation to the nature, extent and workplace experiences towards voice. Within the context of developing economies, construction industry provides an ideal locus for our research. It is argued that the precariousness of construction workers and inherent undesirable characteristics of construction industry would highly likely inhibit workers from sharing workplace concerns and suggestions, thereby providing far more fertile ground for worker silence than voice (see Pyman et al., 2016). The lack of tenure and vulnerability of low-wage construction workers to exploitative workplace practices suggest that their motivation to fulfil basic biological and physiological needs take precedence over others needs such as voice intention, personal development, autonomy and self-realization (Maslow, 1943). This in turn paves the way for the management's overreliance on the traditional carrot and stick policy to induce the desired behavior -i.e. worker silence. As our findings indicate, the workers' silence in our cases was just the well-trained practice of long-term tongue biting - an indication of physiological and safety concerns as the workers' salient needs (see Lance Haun, 2011). 
This study adds to this debate through a qualitative, inductively-oriented examination of the nature and extent of employee voice in the construction industry which is characterized by vulnerable workers with precarious term of employment. Our study contributes to voice literature in several ways. First, previous studies have rarely assessed the practice of employee voice in precarious employment in the context of developing Middle East and North Africa (MENA) region. This limitation is likely to become more as the significance of the MENA region in the global economy and politics unfold and precarious employment relationships continue to play a significant role in boosting the economic growth of the region. More specifically, the non-capitalist labor institutions of MENA economies, the growing dependence on labor-intensive construction operations, vulnerability of workers to precarious employment in the construction sector coupled with the absence of voice-focused HRM practices motivate us to understand institutional forms of voice and the extent of worker voice in practice (see Budhwar and Mellahi, 2007; Wood, 2010; Pyman et al., 2016). Some commentators have argued that workers in precarious work in developing economies have limited avenues to express their voice or feel they cannot freely do so (see Burgess et al., 2013; Wilkinson et al., 2014). Instead, they are most likely to withhold suggestions for addressing ordinary problems and making improvements. The results of the current study therefore extend understanding of the usefulness of the predominant capitalist, Western-derived voice arguments for explaining the forms and foci of voice in developing MENA region economies. Second, we examine whether HRM policies is inclusive of voice practices. While the responsibility of maintaining good industrial relations is mainly discharged by HRM function, previous studies of voicefocused HRM practices have yielded mixed results (see Bryson et al., 2007; Wilkinson and Fay, 2011). In this respect, the current study widens the horizon of international human resource management (IHRM) and voice research through offering insights into the presumed role of HRM as the sole custodian of the workers' perspective generally (see Ackers and Wilkinson, 2003; Budhwar and Mellahi, 2007). Third, this study contributes to the literature on "voice-exit-loyalty" framework (Hirschman, 1970) by illustrating the precarious workers' inability to engage in both voice and exit and their feelings of being stuck and no way out (see Allen, 2014). In this respect, the fulfilment of basic needs of workers was seen to remain a far more attractive option than voice and exit and that loyalty became irrelevant in the workplace. Finally, this study contributes practical insights into HRM issues of both local and international firms operating in the diverse workplace of MENA region particularly with regard to adopting a more proactive role in championing voices for workers in precarious jobs. 
We proceed by presenting an overview of contemporary research into precarious employment and worker voice. Next, we discuss the adopted qualitative research design and methods and we then present the main findings of the study. We conclude by discussing the implications of our research for both theorists and practitioners.

\section{Precarious employment and worker voice: a review}

Kalleberg (2009, p. 2) defines precarious work as "employment that is uncertain, unpredictable, and risky from the point of view of the worker". Four key dimensions express the essence of precariousness (Rogers and Rogers, 1989, p. 3): temporal (low certainty over the continuity of employment), organizational (lack of workers' individual and collective control over working conditions), economic (insufficient pay and salary progression), and social dimension (customary protection against unfair dismissal and unacceptable working practices). Atypical, contingent and non-standard employment such as part-time, fixed-term, temporary, casual and on-call work are examples of precarious employment. Under the insecure and unpredictable nature of precarious employment, risk is transferred to the employee, and the employer bears fewer of the hidden costs associated with regular employment including compensation for redundancy or reduced working hours (see Burgess, 2013, p. 4084). The clearest expression of this position is found in Broschak and Davis-Blake's (2006, p. 371) discussion of the consequences of mixing standard and nonstandard work. They observe that the economic efficiency of nonstandard employment arrangements would make nonstandard workers slack resources. As organizational slack, they serve two central purposes. First, they act as a "ring of defense" and buffering mechanism to protect the job security, mobility opportunities, compensations levels and attitudes of the standard workforce (p. 371). Second, they allow an organization to respond to peaks in demand and adapt successfully to labor market needs and provisions (Bourgeois, 1981; Cheng and Kesner, 1997).

Given that employment or work generally is intimately associated with individual, organizational and other social, economic and political issues, the growth of precarious work has also knock-on effects on both work-related and non-work phenomena. Scholars working within this area have theorized a range of consequences of precarious work that are composed of greater economic inequality, insecurity and instability (Kalleberg, 2009). Researchers have also explored consequences of precarious work for individuals outside the workplace such as physical, psychological and moral dislocation of people, social disengagement from 
mainstream employees, and the adverse impact of uncertainty and unpredictability of precarious work on families and households (ILO, 2015, Standing 2008; Kalleberg, 2009). Taken together, these bodies of literature indicate that precarious workers are likely driven by primitive urges such as physiological and safety needs and that their willingness to engage in higher level-needs such as voice and participation intention is low or deeply questionable at best. As Maslow's (1943) hierarchy of needs theory reveals, a worker's higher needs do not appear unless and until his or her unsatisfied lower needs are satisfied. In the light of the undesirable and unpleasant characteristics inherent in precarious employment arrangements, precarious workers are highly likely to abandon their higher-level needs (e.g. voice and participation) in exchange for silence to fulfil their unmet basic survival needs. This in turn encourages managers to adopt a 'carrot and stick policy' and coerce more efforts and compliance from unskilled precarious workers, rather than to enable them to communicate views on workplace issues to their managers.

The growth of precarious work with its highly undesirable hysteresis effects on employee productivity and organizational performance have in turn inspired deliberation on HRM function in terms of mechanisms related to worker voice and participation to have their say on issues that affect their performance. In fact, studies of HRM and Industrial Relations (IR) are highly suggestive that management of the employment has changed markedly over the past two decades in response to several major trends such as demographic shifts in workforce composition due to globalization (see Macdonald, 1997). Given the characteristics of precarious employment and research evidence that underscores insufficient or even a total absence of workers' rights at work, studies of HRM and IR have made significant advances in arguing for greater recognition of employee voice and participation (see Wood and Frynas, 2006; Wood, 2010; Avery et al., 2011; Wilkinson et al., 2013; Connell and Burgess, 2013).

As an enabler of employee engagement (CIPD, 2010, p.2), voice is considered to be the acme of many theoretical and academic models of HRM (Van Wanrooy et al., 2011, p. 18). Much research on individual employee voice has been dominated by applications of Hirschman's (1970) exit-voice-loyalty framework in which employees respond to dissatisfaction at work by quitting or complaining. Given its multidimensional nature, voice has been conceptualized in different ways ranging from 'having a say over work activities and organizational decision making issues' (Freeman et al., 2007; Wilkinson and Fay, 2011) to viewing voice as 'a countervailing source of power on management actions or perhaps part of a mutual gain 
process" (Dundon et al., 2004). Despite the potential benefits of employee voice, some managers limit employee voice by imposing a strict system of direction, command and control. Equally, employees might also prefer to follow a silence behaviour for reasons such as labelling, alienation fear, and thinking that speak up is nonsense (Milliken et al., 2003; Wilkinson et al., 2014).

As a result of the inherent elasticity of the term (see Wilkinson et al 2010, 2015; Budd et al., 2010), employee voice has found a home in several different disciplines and is now cropping up frequently in HRM, political science, industrial relations and organizational behavior literature (Wilkinson and Fay, 2011). The varied theoretical perspectives and approaches to voice and micro-politics of professional vested interest in its practice have made the very idea of employee voice as a highly controversial subject. As a result, arguments and justification for employee voice have encompassed moral, political and economic reasoning (see Budd, 2014). In parallel with the theoretical development in employee voice, there has also been a surge of interest in empirical scrutiny of the manners in which governments, labour market actors and organizations endeavor to facilitate employee voice (see Wilkinson et al., 2004; Kochan, 2007; Bryson et al., 2007; Wood and Wall, 2007; Menendez and Lucio, 2014). Despite some developments, recent research evidence usefully warns of the false seduction of employee voice and the fact that the adopted voice practices are rather simplistic and fail to resonate with reality as perceived by the employees (Freeman et al., 2007). The pessimistic conclusion of recent comparative literature on Western IR systems is that employer-driven styles of voice and government's initiatives to create an engaged workforce have proved ineffective in overcoming the declining trend of overall worker voice and representation. This has been particularly the case for those workers who are involved in precarious work and stuck in a cycle of short-term and irregular jobs (Burgess et al., 2013, p. 4083). As Budd's (2004) has observed, balancing efficiency, equity and voice has, however, proved to be problematic - largely owing to unregulated markets in developed democratic world.

Overall, previous studies of voice have largely concentrated on workplaces of highly advanced Anglo-American and several other developed economies (Bryson, 2004; Brewster et al., 2007; Mellahi et al., 2010; Freeman et al., 2007; Wilkinson et al., 2014). In consequence, as Menendez and Lucio (2014, p. 382) have observed, "many of the characteristics of the system of employment regulation and management in the UK and the USA, with their weak forms of national labour representation, have farmed the discussion of voice". In addition, the 
assumption underlying the extant voice literature has been that workers are homogeneous and as such voice vehicles are generally designed for mainstream employees (Bell et al., 2011; Syed, 2014, p. 421).

In contrast to the availability of an extensive literature on employee voice in developed economies, systematic research on employee voice in developing economies has been sparse (see Pyman et al., 2016). Overall, scholars interested in comparative studies of employee voice have theorised a range of explanatory variables to account for the differences in the nature and extent of employee voice and the need for examining voice in developing economies. Chief among these are: the far-reaching implications of cultural norms, labour market forces, employment legislation, legal regulations, values/ideologies, industrial relations politics, and the role of non-industrial relations institutions. For example, Chen et al.'s (2013) study of employee voice in China revealed two main findings. First, employees were seen to turn a blind eye to organizational problems. Second, the collectivist culture of the Chinese and other Chinese-majority societies was not conducive to the occurrence of voice behaviour. Similarly, Taylor and Bain's (2005) study of call centre sector in India found that despite strong unionisation in sectors such as banking and telecommunications, the hierarchical character of Indian society served as a barrier to employee voice and that the latter constituted a democratic deficit in the workplace governance of Indian call centres (p. 273). Aguzzoli and Geary's (2014) study of employment practices in Brazil identified inefficient employee voice mechanisms in the formal labour market and ineffective unions in the informal labour market as impediments to safety, health and welfare measures necessary for protection of employees afforded by existing employment legislation. Bae et al.'s (2010) study of HRM trends in Korea and Taiwan found that while some traditional HRM practices are more culturally bound than others, any change in the culturally embedded HRM practices (i.e. employee influence) could be rather temporary and less likely to occur in a short period of time (see for a review Pyman et al., 2016).

Although existing research has greatly enhanced our understanding of employee voice, they entail some limitations. As discussed earlier, most of previous studies of employee voice have primarily focused on highly developed Anglo-American and several newly industrialized economies where employees have extensive access to union and other forms of representation at work. The results of these studies have promoted a homogeneous or universal set of voice arrangements and practices. Integral to most of the employment relations literature are 
developments in the way employee voice is interpreted. In light of the high level of socioeconomic development and opportunities for people to engage in governance and sociopolitical actions in developed economies, a key tendency appears to be an increased emphasis upon viewing voice and participation on ethical and moral terms - as opposed to cost and efficiency-integrated approach to voice (Wood, 2010, p. 3; Brewster et al., 2007). While this line of argument is based upon a 'voice' model of homogeneous and interlinked institutions and presumes that there exist universal employee voice propositions that hold regardless of the context, it can be argued that these findings are by nature context-dependent and are only applicable in those contexts (see Burgess et al., 2013; Menendez and Lucio, 2014; Syed, 2014; Pyman et al., 2017).

In addition, recent employee voice research in the context of developing economies has largely focused on a few emerging economies who have attained a slightly higher degree of socioeconomic development such as certain levels of income, productivity, formal employment, and a range of human capital indicators than many other developing countries (Przeworski et al., 2001, p. 1; Wood, 2010). However, as Wood and Frynas (2006) have observed, "In neither context there is much room for meaningful participation, given both the great weakness of employees, and the intense short-term competitive pressures faced by employers". Under the circumstances, most firms have neither the capacity nor the interest in progressing beyond lowcost, low value-added production paradigms which are characterized by autocratic management. Wood and Frynas (2006) take the argument further and observe that any attempt to invest in people either through significantly higher pay or higher levels of participation will result in competitors seizing short-term cost advantage and the opportunities to enhance organizational efficiency (cited in Wood, 2010, p. 14-15). Wood (2010, p. 15) thus concludes that whilst voice and participation are ethically acceptable and morally desirable in developed democratic societies, firms in developing economies lack the capacity and incentives to move beyond the low value-added labour repressive present and instead voice is subordinated to efficiency (see also Brewster et al., 2007; Budd, 2005, p. 111).

There have therefore been insufficient attempts to stray far from the employees in mainstream developed as well as emerging economics to encompass precarious employment and associated voice mechanisms in developing nations (see Syed, 2014). In fact, the voice literature to date has not proved to be very helpful in unravelling the nature and extent of voice in developing economies of MENA region. With the exception of Connell and Burgess' (2013) recent analysis of vulnerable workers in the Middle East, there has been a substantial lack of research 
into the practice of employee voice in precarious employment in the context of developing MENA region countries. While Connell and Burgess' (2013, p. 4180) study paints a grim picture of deplorable working conditions of workers in precarious employment and offers rich insights into how IR/HRM can effectively influence the improvement of workplace conditions for vulnerable workers, they remain quite disconnected from the lived experiences and perceptions of vulnerable workers towards voice and participation.

Given the preceding limitations and the crucial role of precarious workers in transforming the region's economies, and the continuing disadvantage of workers in precarious employment, the aim of the current study is to examine the nature and extent of voice in a business context that is characterized by an oversupply of vulnerable workers engaged in precarious employment. An examination of the precarious workers' lived experiences with vulnerability is undoubtedly a key factor in their perceptions towards voice and is a classic example of the role of economic and employment context in their interpretation of voice (see Bryson et al., 2006; Wilkinson et al., 2013, p. 268; Wood, 2010, p. 553; Wood and de Menezes, 2008; Story, 1992, p. 65-6).

\section{Research approach}

In line with the aim of the study and the relative paucity of previous empirical research on precarious employment and employee voice in the context of the developing MENA region, we adopted an inductive case study research approach (see Eisenhardt and Graebner, 2007). Case study approach is a preferred and commonly used qualitative method when (i) a researcher's knowledge of the research phenomenon is limited (Yin, 2014), (ii) the aim of the research is to describe a situation which is sensitive to the context in which the research occurs (Miles and Huberman, 1994), and (iii) when the focus of the study is not typicality but the unusual, unexpected, covert or illicit (Hartley, 2004).

\subsection{Research context}

The empirical study was conducted in Iran's construction and building materials and products manufacturing sector. Known as Persia, Iran (officially Jomhuri-ye Islami-ye Iran, the Islamic Republic of Iran) is a sovereign country with geostrategic importance in Western Asia (Frye, 2005). As one of the largest and most populous country in the MENA region, Iran has a population of over 80 millions of which Persians constitute a dominant majority (Encyclopædia 
Britannica, 2017; CIA World Factbook, 2017). Iran officially became an Islamic Republic with a theocratic constitution after the 1979 revolution. As an Islamic republic and a Shia populous country, Iran's constitution offers some religious freedom rights for other non-Islamic schools (e.g., Zoroastrianism, Judaism, and Christianity).

From a cultural point of view, Iranian culture is religious, class based and patriarchal (Price, 2001). While a Middle Eastern country, Iran is not part of the Arab culture. Rather, it is part of the South Asian cultural cluster consisting of such countries as India, Thailand, and Malaysia (Javidan and Dastmalchian, 2003). Javidan and Dastmalchian (2003, p. 127) distinguish Iranian culture from the Arab culture by "its seemingly paradoxical mix of strong family ties, a high degree of individualism, excessive privilege on those in positions of power, zero tolerance of disagreement on top-down management mandates, less emphasis on various future-oriented behaviours, and low gender egalitarianism”.

According to Javidan and Dastmalchian (2003), the dominant hierarchical and directive culture of Iranian society leaves employees and institutions vulnerable to risks posed by egocentric management which presumes that only the boss has the right answers. The religious domination of Iranian culture thus fosters a management style which is to be primarily based on the government's revolutionary ideals and the tenets of Islam (see Javidan and Dastmalchian, 2003: 128; House et al., 2004; Soltani, 2010; Soltani et al, 2014, 2012). In practice, however, it places less emphasis on the participative, shared decision making or leadership elements but gives more weight instead to the importance of keeping pace with top management's stated mandate and objectives. For example, high power distance of Iranian managers is pursued through autocratic leadership and a strong directive approach. Individualism is reinforced not least because individual's interests always take precedence over the group's and organization's interests. The strong desire to avoid uncertainty also acts as a distinguishing feature of Iranian culture (Hofstede, 2001).

Iran has a centrally-planned, state-owned economy with strong government control over major economic activities (Salehi-Isfahani and Pesaran, 2009). As an economically diverse country, Iran has the second largest economy in the MENA region (World Bank, 2015). However, Iran's economy has faced and suffered from myriad colliding crippling internal and external challenges ranging from high unemployment and poverty levels, economic mismanagement and inefficiency, government's dependence on oil revenues and vulnerability to oil price fluctuation. 
The development of HRM in the country is traceable to the certain Islamic values and cultural traditions and to a lesser extent several other socio-cultural institutions. The influence of the Islamic ideology on HRM in Iran is evident in the work of Tayeb (1999) and Namazie and Tayeb (2006). While respect for age and seniority, trust, loyalty and obedience of leaders are familiar ingredients of an Islamic workplace culture and remain pervasive in most Middle Eastern countries, Islamic values place also emphasis on a consultative decision making and participative management styles. It encourages managers to release human potential through trusting their employees' judgement and integrity, effective working relationship, delegation of authority to individual employees and teams further down the hierarchy. However, the actual practice of HRM in the form originally envisaged by the Quran (the sacred scripture of Islam) has not so far developed.

Under the Islamic Republic of Iran Labour law, Shora-e Islami Karagaran (Islamic Labour Councils) acts as the primary custodian of worker rights at work. In an attempt to defend the legitimate rights of workers, workers can only join the following three authorised types of organisation: a) Islamic labour council, b) trade association, and c) worker's representative. While the labour law stipulates the right to collective bargaining and contract, a recent joint report by International Federation for Human Rights and League for the Defence of Human Rights in Iran (FIDH and LDDH, 2013) found no evidence whatsoever to substantiate its assertion about the 'right to strike' since the Islamic revolution of 1979. Further details on Iran's socio-economic, cultural and political context is presented in Table 1.

\section{[INSERT TABLE 1 ABOUT HERE]}

\subsection{Research site}

To reflect on the observable reality of employee voice, construction and building materials and products manufacturing sector was chosen. As the largest industry in the MENA region, the construction and building materials sector has experienced significant growth in recent years for two main reasons: (i) an increase in national and international investments in post-war reconstruction period, and (ii) the government's willingness to generate a more diversified (non-oil/gas) industrial base and promote non-oil exports and revenues (see Kalb, 2014; Business Monitor International, 2016). The reasons for choosing the construction sector is attributed to the inherent undesirable characteristics of construction industry, namely, poor image, temporary and insecure employment, lack of opportunities for training and skill 
formation, and the most attractive industry for the employment of low-paid, unskilled workers. In fact, Iran's construction boom and throngs of unskilled and cheap foreign workers who are often illegal residents have provided an unprecedented opportunity for employers to reduce costs and secure superior profitability (Karimi Moughari, 2007). As a result of the 36-year USled international sanctions on Iran (1979-2015) and high unemployment rate among mainly educated and semi-skilled local workforce (perhaps as high as $11 \%$ in early 2016), Iran has only been as an attractive place of work for unskilled workers from several neighbouring countries such as Afghanistan (over 98\%), Iraq (1.5\%) and Pakistan (0.5\%). Most of foreign workers are not only involved in 'dirty, dangerous and demeaning' (3Ds), low-paid and unskilled construction jobs, but also are subject to the extreme discrimination (see Connell, 1993; FIDH \& LDDH, 2013).

\subsection{Selection of Cases}

In selecting the number of cases from the two industries we followed the case selection strategy recommended by Eisenhardt (1989). Based on the notion of 'theoretical sampling', we chose a sample of 6 cases - out of a pool of 24 companies. While there is no ideal number of cases, Eisenhardt (1989, p. 545) recommends 'a number between 4 to 10 ' to establish a stronger base for theory building. For the purpose of theoretical sampling of the 6 cases (referred to in this research paper under the pseudonym of Const1, Const2, Const3 \& Mfg1, Mfg2 and Mfg3), each case had to conform to several criteria: (i) level of access to key informants as well as to company/employee records, (ii) HRM department with its own VP, and (iii) recruitment of diverse pool of work groups in terms of generic and specific employability skills. Overall, the choice of multiple-case study design enabled the research team to clarify whether the perceived employee voice was simply idiosyncratic to a single case or consistently replicated by several cases across the two industries (Eisenhardt and Graebner, 2007, p. 27). Table 2 presents further contextual information of the cases.

\section{[INSERT TABLE 2 ABOUT HERE]}

\subsection{Data collection}

In line with Eisenhardt and Graebner's (2007, p. 28) recommendation, we used interview as the primary source of data. We also employed other qualitative data collection methods (e.g. focus group meetings, archival data/company policies and informal discussion) to provide 
stronger substantiation of constructs and findings (Eisenhardt, 1985, p. 538). The process of data collection started by identifying the key informants or "gatekeepers" who could facilitate our access to the organisations, recommend other informants (i.e. the snowball sampling), and provide information about: knowledge of employee voice and participation, organisational approach to voice, voice-focused HRM policies and practices, concerns that can (or cannot) be raised openly at work, ability and willingness to express concerns at work, reasons for speaking up or silence about problems, consequences of raising concerns or remaining silence at work, and forces that drive and inhibit employee voice at work. Overall, we interviewed 30 managers and 62 employees across various hierarchical levels, different functional specialties and at different operational sites across the country. The length of each interview varied from 60 to 90 minutes. All interviews (with the exception of 11) were conducted in Persian and backtranslated into English. Table 3 presents descriptive statistics on interviewees in each case.

\section{[INSERT TABLE 3 ABOUT HERE]}

To effectively design and develop the individual face-to-face interview protocol (see Hennink, 2014), we initially held six focus group interviews (one per case). The length of focus group interviews ranged from 2 to 2.5 hours (including a 15-minute break). In terms of the composition of focus group interviews, the participants included both managers and employees. Given the high-power nature of Iranian culture and paternalistic leadership style (see Javidan and Dastmalchian, 2003), we divided the activity of focus group into two sessions. In the first session (i.e. first hour of the focus group discussion), the composition of the focus group in each case included both managers and employees. There was clear evidence that nonmanagerial employees were reluctant to express their opinions in front of their managers and that they often waited to learn about their managers' perspectives - owing to the fact that any disagreement could jeopardize their jobs. While such heterogeneity among the participants enriched the intergroup dialogue, we continued the second session of the focus group discussion in each case with only non-managerial employees. Such homogeneity among participants not only reinforced employees as a group, but also, resulted in a greater dialogue (Kruegar, 1994; Silverman, 2011). Table 4 presents a summary demographic profile of the focus group participants.

[INSERT TABLE 4 ABOUT HERE] 


\subsection{Data analysis}

To facilitate the process of analysis, data collected from other sources (i.e. archival data, company policies, informal discussion, and focus group meetings) were converged with the verbatim transcripts of the interviews. In a manner consistent to that of previous qualitative research (e.g. Waldman et al., 1998; Harris and Ogbonna, 2002), we followed the procedures outlined by Corbin and Strauss (2015) in that we directed our efforts at discovering regularities in the data through open, axial and selective coding. To this end and prior to coding the transcript sheets, we followed the "pattern matching" approach (i.e. comparing predicted/expected pattern of variables to the empirically observed pattern) and prepared a descriptive keyword process. The text was then coded according to the variables specified in the predicted pattern of variables (see Yin, 2014; Waldman et al., 1998, p. 185-6).

Consistent with Corbin and Strauss' (2015) recommended procedures, the coding process of the transcript sheets was conducted as follows. Open coding constituted the first level of conceptual analysis. We began by 'fracturing' or 'breaking open' the data through line-by-line analysis of the transcripts and thereafter specifying different properties of the research phenomenon. As a result of open coding, several (provisional) conceptual categories were identified and subsequently compared and revised to reflect only on those categories which were integral to the data (e.g. four factors contributing to immature understanding of voice; five factors contributing to wider impact of organisational/environmental factors on voice and silence; three factors explaining the blurred boundaries between the rhetoric of ISO/industryspecific quality standards as employee participation tools and their reality as means of work intensification and heightened management control; four bases for inclinations towards compliance and silence; and four factors explaining consequences of voice and silence). Axial coding was then employed to make connections through those categories that were emerged from open coding. The focus here was on linking and interrelating each emerged category with their subcategories. Finally, selective coding was used "to integrate and pull together the developing analysis" (Corbin and Strauss, 2015, p. 188) to further develop and refine theoretical claims. This process involved selecting the core (or main) category through a thorough review right from the start of the analysis to the final decisions about the core category, assessment of a logical and systematic relationship with other categories, and the process of the validation of these relationships. 
In order to mitigate potential bias in interview data and address the validity of the developed framework, we followed the procedures akin to that of Harris and Ogbonna (2002, p. 37) that utilized both internal and external validity checks (see Eisenhardt, 1989). The coded transcripts and the relevant results were reviewed and checked independently by the research team. Whilst there was a high agreement rate, we further resolved any outstanding disagreements through consultation with an experienced qualitative researcher who was a faculty member of a local university and an independent consultant specializing in HRM (i.e. expert review). To further enhance the accuracy of our final decisions about the core categories, 18 ex-post interviews with both managers and employees were undertaken and any arising discrepancies were subsequently discussed and resolved.

\section{Findings}

As a result of the preceding research procedures, several categories were found to be our emergent frame for further comparative analysis of the practice of employee voice across the case organisations. Table 5 presents a summary of the key themes, the supporting evidence and additional illustrative quotations for the themes. Comparison of the aggregate responses of managerial and non-managerial informants across the case organisations form the basis for reporting the results of the data analysis that follows.

\subsection{Managers' perceptions of voice and participation}

\subsubsection{Level of awareness of employee voice}

Most of the managers viewed voice as a synonym of communication between employers and employees in the workplace. There was general agreement amongst the managerial informants that supervisory-level managers provide a focal point of reference for employees to communicate their ideas and concerns with the organisations on a regular basis. To this end, weekly briefings by supervisors assisted employees to be engaged in direct communication with their line managers and this in itself provided the avenue for them to share ideas and concerns directly and openly and get to know new developments within the organisation. However, our analysis of the data suggested that managers were inclined to spell out their own expectations about how they wanted employees to express concerns to their supervisors. One 
construction manager captured the feelings of many managers on their understanding of the term voice as communication:

The idea is to get the job done and as fast as possible. So employees have every right to be aware of organisation strategies, goals and objectives. We communicate all specific targets and expected working behaviours to our employees and have directives on helping employees perform a specific task. [Project manager, const1, aged 39, 8 years' service]

Archival research revealed a variety of communication devices of all kinds (e.g. weekly briefing meetings, company's training videos, quarterly newsletters, annual reports and media releases) that were utilised to help employees become effective participants in organisational affairs that affect their work. However, our analysis of the data would suggest a need for caution in interpreting the logic behind the adoption of such whole gamut of communication devices. While internal communication is expected to enhance employee motivation and willingness to go above and beyond their job descriptions and voice their concerns freely, it appeared that whole gamut of communication devices were merely devised to transmit inflexible policies and directives from the top to lower-level employees. As one supervisory level manager observed:

We have to enforce company policies strictly. Employees have to perform in accordance with the written policies. For whatever reason, we do not expect lower-level employees to question the effectiveness of organisational policies. [Site supervisor, mfg2, aged 44, 11 years' service]

Overall, our managerial respondents were reluctant to honour their basic obligations to raise awareness among workers of their many basic rights or educate them to express their thoughts and suggest new ideas at work. The commitment of lower- and middle-level management to enforce top management directives resulted in primarily one-way (downward) communication in which subordinates were found to lack decision latitude.

\subsubsection{Dimensions of employee voice}

The essence of the idea of employee voice across all six cases was built on the twin dimensions of (i) participative management and (ii) formal grievance procedures. Further discussion of these issues is provided below. 
(i) Participative management: In all cases, the method of introducing participative management largely hinged on organisation-wide continuous improvement programmes. In order to empower employees to have a say in work-related issues, the case organisations placed a heavy emphasis on one- to two-day workshops for managers across various hierarchal levels. Functional and unit-level managers were then instructed to offer introductory quality and safety management training courses to lower level employees. The quality control coordinator's reflections on these quality and safety training courses are illuminating:

I have found ISO quality management and safety workshops to be instrumental in connecting to employees and make them feel engaged at work. Although ISO standards covers all aspects of quality and safety management, we expect our employees to be rule-followers. So the fact is that we use ISO and related quality improvement techniques to strictly enforce organisational policies. [Site quality manager, mfg1, aged 43,8 years' service]

In a similar vein, the regulatory-driven nature of employee participation is revealed in the following comment by one assistant site manager:

Quality and safety standards are very instrumental in facilitating workplace relationships and enhancing the overall quality of life at work and workforce productivity. This is mainly because construction industry is prone to many hazards and we need our workforce to follow quality and safety policies and eliminate the risk of occupational accidents. Therefore, when employees observe workplace rules and policies it means that they have adequate awareness of workplace issues and are in a position to inform us of their suggestions and concerns. [Assistant site manager, const3, aged 51, 12 years' service]

There was a definite interest in adopting an ISO-9000 compliant quality system as (in the words of one construction manager) "the first step which provides a guarantee to bid different contracts in construction industry". Notably, the manager continued by saying:

We are all aware that compliance with internal quality and safety policies and regulatory requirements has the potential to bring about both quality improvement and workplace safety. But the reality is that we do not go beyond the minimum quality, occupational health and safety requirements of the industry. We 
communicate workplace policies and procedures to our workforce under the umbrella of ISO quality management system. Under ISO system, the level of employee participation is limited to pure compliance with top-down management programmes, policies etc. [Site manager, const2, aged 40, 18 years' service]

Overall, it was difficult from the analysis of the managerial responses to disentangle the effects of ISO certification on creating a participatory and healthy work environment from the whole array of industry-specific and legislated occupational safety and health mandates. While all case organisations were voluntarily taking a range of quality and safety initiatives, there was clear evidence that (in the words of one safety and health coordinator at const1) they primarily "played a regulatory role" in enforcing quality, health and safety standards at work. However, as our analysis of the data showed, these operational and strategic priorities were neither translated into a markedly changed healthy work environment nor obliged the case organisations to protect the needs, rights and well-being of the workers beyond the basic welfare state regime.

(ii) Grievance procedures: All case organisations appeared to have similar grievance procedures in place. Although the researchers had no access to employee grievance records, a majority of managerial respondents viewed formal grievance procedures as the focal point of reference for employees to receive prompt responses to workplace problems and concerns. The importance of formal grievance as a surrogate measure of the level of employee voice for a majority of middle and lower level managerial informants was a response to the 'periodical labour inspection visits'. As one manager put it succinctly:

Awareness raising for health, safety and quality requirements and ensuring worker compliance with policies are routine tasks in our organisation. We communicate policies and procedures under which employees need to work. In case of any concerns, employees have the opportunity to file a grievance. The organisation's grievance procedures would help us avoid administrative penalties imposed by labour inspectors. [Production manager, mfg2, aged 38, 10 years' service]

However, labour inspection was primarily associated with the high risk of occupational injuries of construction and manufacturing industries. As one manager observed:

Construction is a very dangerous sector and by nature it is mainly a manual work. Workers are very much aware of high fatality injury rate, poor working 
conditions, late shifts, and overtime work. We provide the necessary work instructions and guidelines to all employees in accordance with the regulatory and safety requirements. [Facilities manager, const2, aged 44, 15 years' service]

Further analysis of managerial responses highlighted two key elements as the essence of the grievance procedure across the case organisations. First, unfair dismissal, deduction of wages, and poor working conditions were the most common sources of employees' grievance at work. Second, line managers and occasionally HR departments were seen to form the final steps in resolving workplace problems. The cautious, hesitant character of the grievance procedure of case organisations is revealed in the following analysis made by a lower-level manager:

I can say in nearly all cases worker's immediate supervisor resolve the grievances. We rarely discuss employee grievances with our line or top management. We resolve them without any interference by our line managers. We do not want to be labelled as incompetent supervisors by higher-level management as this might jeopardize our own job security. [HVAC supervisor, mfg3, aged 39, 12 years' service]

Overall, the analysis of managerial responses indicated that the grievance procedures were rarely sufficiency targeted at voice and participation activities and this in turn gave little opportunity for the exercise of discretion to influence work. Despite the potential benefits of ISO 9000 quality management standards for upward communication and employee participation, they were used as easy mechanisms to give an impression of managerial actions in respect of employee voice which, in truth, were seen as favourable for tightening managerial control and obtaining desired results from the workers.

\subsection{Employees' perceptions of voice and participation}

\subsubsection{Level of awareness of employee voice}

Evidence from various sources of qualitative data pointed to a heightened consciousness of the importance of voice practices as an area for concern. Across the case organisations, employees' awareness of voice was limited to the rights to job safety and basic wage contained in the employee handbook. Close analysis of employees' awareness of employment rights and their exercise of those rights revealed quite clearly that they had no comprehension of 'voice' as an effective and valuable employee tool. One worker summarised what was happening: 
All we know about employee voice comes from the employee handbook. This is what the reality is. We all have a lot of work-related information that can help management make better decisions. But they do not ask for our views. When management team face a problem, they recruit consultants for advice. We cannot raise any issue without being asked. [Glazier, const3, aged 40, 13 years' service]

Across the case organisations, the amount of 'upward communication' or (in the words of a cement mason worker at const1) "true voice" left extensive uncertainty and confusion about the exact nature of employee voice. Instead, a majority of employees had taken the safe response of silence as the cue to an "unjust working environment" and "fear of job loss". This was in particular the case for foreign workers who were routinely deprived of their basic rights such as favourable work conditions and equal pay for equal work. As one foreign worker observed:

Our boss knows that we are here for economic reason. They know that we come from a country that our basic needs have been left unmet for years. So we all prefer to keep mum and get paid. We do not know much about voice or even do not want to have our voices heard. [Concrete finisher, const2, aged 30, 7 years' service].

Overall, the state of play of employee voice across the case organisations was rather uncertain. "We have to agree to take on whatever is asked without asking any questions" was one of the most frequent responses to the level of employees' awareness of workplace voice and participation - an indication of silence as a learned behaviour and realising that refusing or challenging what a manager asks or wants isn't the way to fulfil their unmet physiological needs. The enduring impression was that employees were increasingly of the view that voice and participation were rarely given much credence by the management. In the absence of structured, organisation-wide diffusion of voice-focused activities there was not only a continued ambiguity surrounding the very idea of voice, but also employees appeared not to have a comprehension of voice as a powerful tool for providing management a sense of the reality of the organisation.

\subsubsection{Dimensions of employee voice}

As we previously discussed in our analysis of the data, two main issues emerged with respect to the essence and nature of employee voice across the case organisations: (i) participative 
management, and (ii) formal grievance procedures. The employees' perceptions towards each of these issues are discussed below.

\section{(i) Participative management}

Across the case organisations, the management team were perceived ignorant of the employee basic rights and fundamentals of continuous improvement programmes such as ISO standards. The ad hoc nature of participative management approach was revealed in a number of regards. The top-down and closed vertical communication approach to the adoption of ISO standards fostered blind compliance to the rules. As one concrete finisher at const 3 put it succinctly, "The ISO and improvement programmes have created a culture of obedience and blame". Moreover, the intended goals of the so-called participative management were not linked in any coherent manner to the notion of employee voice or the broader HRM strategy. According to one brick and tile making machine operator at $\mathrm{mfg} 3$, the notion of participative management under the name of ISO and quality management programmes equated to a zero error tolerance policy an indication of intensified managerial control to minimise performance variance. The consequences emanating from just paying lip-service to employee voice under the participative management regime were indicative of communicating top management directives which in turn demanded unquestioned obedience from the employees. One worker reflected on the resulting implications for the nature and extent of employee voice and participation:

We have to be quiet, listen and do whatever they want us to do. That is all we need to do to keep our job and get paid. Or if we wish to say something it should please them or at least should not be different from what they think. So participative management for us is to report our performance deviation and be held accountable for any deviation for whatever reason from the desired outcomes. It is not to do with our own concerns about work. It is meant to put employees in a more compliance mindset. [Floor technician, const2, aged 28, 5 years' service]

As many non-managerial informants noted, the existing occupational safety standards were designed in ways which gave little opportunity to unskilled workers for the exercise of task discretion, autonomy and work control. Rather, they were arranged in such a way that encouraged managers to invest little in methods and mechanisms which could promote voice 
and participation in identifying and solving workplace problems. Perhaps most telling on this point is the following comment made by a migrant worker:

We even cannot report any fault and work-related incidents that adversely affect our performance. Because if we speak up we would definitely take the blame and highly likely lose our jobs. We know that our temporary contracts and low wage have secured us a job but they have equally made us even more vulnerable to exploitation. So the easiest option we have is to stick our heads in the sand and forget about our concerns for our rights and organisation. [Concrete cutting/drilling operator, const3, aged 47, 13 years' service]

In short, there was a strong belief by many employees that the opportunity to participate in organisational affairs under ISO and continuous improvement factory regime was frequently undercut by excessive control and rigid adherence to ISO standards. Consequently, employees viewed the so-called participative management style as merely an attractive idea in the abstract. In practice, however, they were chary about their actual involvement in analysing workplace problems, developing strategies, and implementing solutions. The prevailing view was that participative management approach had only led to a strengthening of managerial power where "employees were scared to death to share their true thoughts and report bad news to line managers" [Mason tender, mfg2, aged 36, 6 years' service). "Don't speak unless you are spoken to" was one of the most frequent responses to the nature and extent of participative management in the case organisations.

\section{(ii) Formal grievance procedures}

The non-managerial respondents did not perceive the notion of grievance procedure as a platform to bring their feelings of dissatisfaction or injustice about their job or the organisational policies to the attention of the management. Data analysis suggests that employees were expected to embrace and embody the disciplinary policies and procedures and that they might file a grievance only in exceptional circumstances. The comments of one worker exemplify the nature of grievance procedures:

You know the kind of job that we do is temporary in nature. Although most of us have a kind of opened-ended contract, they can terminate our contract at any time. We rarely complain about the working conditions as we have learned by experience that this is something that we have to live with it. We do our best to keep our head 
down in order to keep our job. It is more of the job than anything else that matters most to us. [Scaffolder, const1, aged 29, 10 years' service]

A similar quotation from one foreign worker at one of the manufacturing cases summarised the general feeling:

We all try to be fully compliant and abide by the organisational rules, which mean we should work hard, keep silent and avoid reporting workplace difficulties, no matter what the labour law says. This is because we fear of losing our job. We need our basic human needs to be fulfilled and prefer not to talk about our workplace rights. We work for shelter and food and to support our families back home. Of course our boss is also desperate for cheap work that we offer. [Brick kiln worker, mfg3, aged 39, 12 years' service]

Evidence from the interviews and archival research pointed to the role of precarious work of construction industry and vulnerability of construction workers in influencing a worker's degree of willingness to file a grievance about working conditions or workplace relationships with managers. In fact, there was a general agreement amongst workers that the poor image of the construction work coupled with their personal background (e.g. migration status of foreign workers) provided a focal point of reference which determined the extent to which they could voice their concerns. Ironically, these issues coupled with fear of losing job reinforced a culture of silence as they made it difficult for workers to raise concerns about workplace affairs. All non-managerial informants were more frustrated in their inability to even complain about unpaid or delayed wages not least because they felt temporary employment and low wage were their unique selling points. As one experienced foreign ironworker at $\mathrm{mfg} 2$ observed: "it is therefore safer to keep it to ourselves and friends and follow manager's ways of doing things. All we need is steady job and income".

Overall, employees appeared to be left on the sidelines of grievance procedure and that they found the existing option available to them to be ineffective and risky to choose. Many informants questioned the motives of grievance procedures and doubted if they were geared towards tackling issues that had negative effects on their morale and productivity. The most notable aspect of disciplinary and grievance procedures with regard to employee voice was that there was far less emphasis upon fostering positive workplace interactions between employees and their managers. On the contrary, as one foreign worker at mfg1 case explained: "it is often the case that we get punished for filing a complaint, no matter what the reason is. It is rather 
impossible for us to prove that we get punished intentionally" - an indication of fear of retaliation and consequently inability to report workplace issues that adversely affect employee performance and behaviour at work.

\subsubsection{Manifestation of employee voice}

Further analysis of the employees' responses highlighted one broad way in which employee voice was manifested across all cases: hierarchy. In fact, non-managerial employees responded as if employee voice was more of (in the words of one tile setter at $\mathrm{mfg} 1$ ) "managers' concerns for productivity improvement and labour law compliance”. Across the case organisations, employees emphasized the importance of understanding the distinction between managers and subordinates under the dominant top-down organisational culture. Experience with the case organisations suggested that employees always reminded themselves of the dominant 'command-and-control' management style, which had the potential to narrow a manager's vision and revert him/her to authoritative control - an indication of self-centred mentality of managers who think too much of themselves and make employees feel inferior. The following examples make the nature of the manifestation of employee voice sufficiently clear:

The kind of norms and values that we have to respect in the workplace is to accept the power and authority from the top. So the higher you are in the organisational hierarchy the more say you have. It means managers spend more time on fulfilling their own self-interests. We do not have hierarchical power. That's why managers do not trust us to make decisions on our own. [Concrete mason, const2, aged 34, 9 years' service]

The position that you hold in the organisation determines the degree of the voice that you can have. We do not have any other option but to respect it and like it. We are at the mercy of our managers due to our insecure employment conditions. We work very long shifts and we are dead-tired. We cannot think of anything else but to keep our jobs and to meet our basic needs. [Auger-pressIR operator, mfgt3, aged 42,22 years' service]

Possibly the best example of the influence of hierarchy on voice is related to foreign workers who believed that management undermined their basic rights and concerns (e.g. written employment contracts, substandard on-site living conditions). Foreign workers were perceived 
to be economically and socially inferior workforce and that this had in turn given local workers a de facto position of privilege. As one foreign worker at mgf3 observed:

We are at the mercy of our bosses because we have weaker job security compared to other workers. So if we wish to say something we first think about the consequences in terms of our job and pay. We are not expected to talk about our concerns or work-related problems. We know what our boss wants from us and how to deliver it to his satisfaction. The only right that we have is to remain silent. We cannot really afford to talk [Brick \& tile making machine operator, $\mathrm{mfg} 3$, aged 36,7 years' service]

Overall, for a majority of non-managerial informants the main variable at play appeared to be hierarchical decision making in a sense that organisational choice about employee voice laid at the top of hierarchies rather than employees' expectations and desires for voice. Our analysis of employees' responses indicated that it was the top-down, rule-based, economic logic of action and the need for operational compliance initiatives which most contributed to the management choice about the nature and forms of voice that they wished to put into effect in their organisations.

\section{Discussion}

The aim of this study was to examine the managers' and employees' perceptions of voice in the construction and building materials manufacturing sector. By treating voice as both (in)direct and (in)formal involvement of employees in influencing organisational decision making (see Wilkinson and Fay, 2011), the study revealed insights into an immature understanding of voice and the lingering confusion over voice and participation at work, factors contributing to the deep rifts over the actual practice of voice and the ideal principles underpinning it, the manners in which voice practices were manifested, and the resulting ramifications for the workers concerned. By examining the findings, we explicate the resulting implications for both theory and practice of employee voice as follows.

\subsubsection{Theoretical implications}

Our study contributes empirical insights into the impact of statutory, regulatory and quality compliance on shaping the nature and extent of employee voice and participation within the 
context of developing economies. Past studies of employee voice correlate voice and participation to the economic and employment context in which voice schemes are introduced (Wood, 2010; Wilkinson et al, 2013, p. 268; Menendez and Lucio, 2014). Our study adds to this knowledge base which builds on the 'complex and multifaceted notion of socio-economic development' (Przeworski et al 2001:1; Wood, 2010). Prior literature has long viewed voice and participation as a major growth area in employment relations of developed nations who have attained a high degree of socio-economic development in particular with regard to formal employment, highly developed capital and labour markets, and high human capital indicators. In consequence, organisations encountered in developed economies have embraced both the regulatory mandate for employee voice as well as management-sponsored voice mechanisms to elicit greater discretionary effort from employees that enhances the organization's performance (Wilkinson et al., 2013, p. 268; Gomez et al., 2010). In contrast, our sample organisations in developing context of Iran appeared to give more weight instead to unquestioning obedience to statutory, regulatory and quality requirements. The blind obedience to hierarchical authority and rules proved, however, to stifle voice and participation and deter employees from reporting non-compliance incidents due to fear of repercussions. This finding is concordant with recent research which argues that different phases of societal and economic development and institutional evolution is conducive to different forms of employee voice and participation (Wood, 2010). As a result, employee voice and supporting participatory mechanisms in countries with low degree of socio-economic development (particularly in terms of persistent high unemployment, low productivity, low global integration, the absence of labour union representation, and lagging political and institutional reforms) is fundamentally different from the popular power-sharing and representative participation in advanced industrialised economies. Hence, our study responds to some theorists' observation (Wilkinson et al., 2013, p. 268; Wood, 2010) about 'the contingent nature of employee voice upon the wider societal and economic development environment in which an organisation operates' (see Wilkinson et al., 2015) and recent calls for additional empirical research into "voice across borders" (see Menendez and Lucio, 2014, p. 381; Pyman et al., 2017). In formal terms:

Proposition 1. Employee voice and participation framed solely in terms of statutory, regulatory and quality compliance will (a) discourage employersponsored forms of direct voice, and (b) limit employees' willingness to express concerns at work. 
Our study extends past research on Hirschman's (1970) exit, voice, and loyalty framework within the employment context (see Donaghey et al. 2011; Allen, 2014). Prior literature has long suggested that employees have the ability to influence organisational affairs by making a choice between exit and voice. Our study provides another lens to comprehend the application of Hirschman's (1970) framework within the precarious employment context of construction sector. As our findings suggest, it is a moot point whether employees have any power to either exit or voice and whether employees are interested in exercising their available responses (i.e. exit or voice) in the face of deteriorating working conditions and unhealthy workplace relationship. Specifically, workers in precarious employment have numerous reasons to be despondent on the both ends of exit-voice continuum and left in the midst of employment changes and challenges. The ability of construction industry to "absorb the excluded" had made the choice of both exit and voice an impossible option for the workers and this in turn made loyalty all but an entirely irrelevant concern for employees (see Souza, 2000; ILO, 2001). Instead, evidence was found which resonates with the notion of "neglect" (Donaghey et al., 2011; Allen, 2014) in the sense that precarious workers were forced into silence and felt it was "better to be quiet and thought a fool than to talk and be known as one" (Perlow and Williams, 2003, p. 1).. These findings bring us to propose:

Proposition 2. Employee willingness to use voice and exit is contingent upon forms of employment and industry characteristics.

Our findings contribute insights into the debates on whether voice and participation should be viewed as a moral imperative (Budd, 2004; Budd et al., 2010) or whether the efficiency rationale should be assumed to be paramount (Brewster et al., 2007). In contrast to viewing voice and participation in moral terms for promoting fairness and democracy at the workplace in developed economies, our findings provide support for organizational efficiency argument in the context of the case organizations. In this respect, our findings correspond to human relations tradition which signals a more cost- and efficiency-integrated approach to guiding the management of employee voice and participation (see Wood, 2010; Brewster et al., 2007; Bruce and Nylan, 2011). Prior literature on human relations approach has long suggested that "soft and skills" training would make employees successfully communicate and convey information to the management and make the workplace a more efficient and worker-friendly place. According to this view, employee performance is the dependent variable and is subject to those employee voice interventions (i.e. soft and skills training) which their adoption, 
adaptation and diffusion lie at the managerial discretion and choice (DuBrin, 2007; Bruce and Nylan, 2011). As our study shows, such conventional economic reasoning did not result in releasing voice and deepening employee engagement, owing to the fact that they lay stress on 'costs' in the form of headcount and keeping the workforce closely matched with requirements in terms of both bodies and behavior (Price, 2011). The dominant hierarchy and compliant rulefollowing culture of the case organizations resulted in employee voice and participation to have no value on its own but as desirable only if it can improve economic performance of firms (see Budd, 2004; Adams, 2005; Wilkinson et al., 2014). In addition, proponents of employee voice and participation in developed democratic and ethical societies have long argued that both objectives of moral legitimacy and business case are mutually reconcilable and that fundamental standards of efficiency, equity and voice should be observed as human rights by individuals, corporations and governments (Budd, 2004; Adams, 2005, pp. 111, 115; Wood, 2010). In contrast, our case organizations as well as many of those in the developing MENA region appear reluctant to optimize efficiency, equity and voice - let alone to balance them. A recent PwC Middle East Publication (2007, p. 5) reveals that the exceptional economic growth in the region has not coincided with equally buoyant labor and human resource development such as voice and participation of workers. Hence, it can be proposed that:

Proposition 3. The logic of employee voice and participation adoption in developing economies is more suited to achieving economic efficiency than moral outcomes, especially when voice and participation are framed solely in terms of statutory, regulatory and quality compliance.

Our study expands past research on precarious employment, worker behaviour, and the role of HRM in reducing worker vulnerability in the context of developing economies (Burgess et al., 2013; Connell and Burgess, 2013; Piasna et al., 2013). Whilst recognising that precarious workers are particularly vulnerable to degraded employment conditions, the motivation of construction workers to fulfil their lower level deficiency needs (see Maslow, 1943) rather than higher-order needs such as voice and participation intention constitutes a value-added empirical contribution. The picture built up from the case organisations was that internationally recognised legal and claimed human rights for workers were neither sufficiently integrated into the employment law nor effectively translated into the HRM practices of the case organisations. The passive role and ambiguous position of Supreme Labour Council in terms of recognising "the right to work" (FIDH \& LDDHI, 2013, p.8) paved the way for the management of case 
organisations to unilaterally devise a personnel management system which perpetuated fear and nurtured a silent epidemic. In an attempt to codify labour standards and employment practices, the management of case organisations activated the personnel management approach through several key levers, namely, the use of temporary employment agencies as a primary source of recruitment of workers, one-off mandatory health and safety training at the beginning of employment contract, over-reliance on a piece- rate compensation system, and employer's sole discretion to dismiss workers on an on needed basis. Under the circumstances, managers were seen to be consciously aware of the fact that precarious workers were highly motivated by their 'unfulfilled' basic-order needs such as physiological hungers and safety needs. Our study therefore contributes to the literature that points to an emerging global phenomenon with a growing evidence base particularly from the developing MENA region economies where the motivation of precarious workers to meet their 'unfulfilled' basic human needs take precedence over other needs such as voice and participation intention (see Burgess et al., 2013; Connell and Burgess, 2013; Piasna et al., 2013; Dundon et al.,2007). Past conceptions of employee motivation have proposed a myriad of individual motivational factors at work ranging from needs, satisfaction, expectations and goal. In this respect, our findings correspond to Maslow's hierarchy of needs theory in a sense that the fulfilment of unfulfilled primitive needs take precedence over other needs. While Maslow (1943) argued that everybody is capable and has a desire to move up the hierarchy of needs towards the growth or being needs, such desire has proved so futile for precarious workers who have often left on a lower survival levels of physiological and safety needs. Overall, our findings highlight some grain of truth in what Wittgenstein once said paraphrasing Kant, "One cannot philosophize on an empty stomach" (Mays, 1968, p. xx; cited in Gobar, 1968) and remind us of Aristotle's (2011) early observation that 'all paid work absorbs and degrades the mind'. Accordingly, we propose that:

Proposition 4. Vulnerable workers in precarious employment are motivated by the perceived opportunity of meeting lower-level deficit needs than higher-level voice and participation needs.

\subsubsection{Policy implications}

Given the Iranian rigid, rule-based and hierarchically oriented culture and the IR context, our findings provide important policy implications for the labour and social affairs officials attempting to protect employees' rights at work. In developed economies, governments have 
made concerted efforts to promote synergies between the IR systems and HRM practices for creating an environment conducive to open communication and mutual trust and respect of managers, workers and their representatives. However, the labour law reforms and employment protection policies in Iran (and other developing MENA region economies - see Connell and Burgess, 2013) were reported to leave the labour market without an appropriate channel for employee voice. In order to secure economic prosperity in Iran's post-sanctions era, the onus is on the policy makers to sharpen the competitive edge by providing a more stable business environment which is conducive to employee voice and participation (see Soltani et al., 2010, 2012). In addition to economic diversification and attempts to reduce reliance on natural resources, a key consideration for policy makers is to lay stress on those structural reforms that are vital for the country's inclusive growth (see Dusek, 2015). Of these, the formulation of a comprehensive employment strategy which takes account of fundamental workers' rights and international labour standards represents a key opportunity to enhance competitiveness of the economy (see Soltani, 2014). Relatedly, government should take extra care to make sure that the labour law is translated into the HRM systems of businesses and that the latter function to the advantage of the employee's right to voice (see FIDH \& DDHI, 2013). While the postsanction era represents a potentially transformative movement for Iran's economic future (Dusek, 2015; Guardian, 2015), the viability of the economy eventually necessitates a clear imperative to nail workforce voice and participation and "getting to the heart of what matters to them" (Varhauser-Smith, 2013).

\subsubsection{Limitations}

We recognize several limitations in our study which in turn highlight a number of new avenues for further research. The current study focused on the nature and extent of voice and participation for workers engaged in precarious employment in a sample of privately owned construction and building materials \& products manufacturing firms in Iran. Future research could explore and analyse the adoption and diffusion of voice practices across different economic sectors with a focus on both mainstream and non-mainstream employees. Given the increased presence of international firms in Iran and potential transferability of their management practices, additional research could focus on voice and voice-focused HRM practices of foreign businesses operating in Iran. Our findings are based on an Iranian sample. The MENA fastest growing construction market in the world and regional expansion of precarious employment would suggest to replicate the findings outside Iran with a particular 
focus on other countries in the MENA region such as the Gulf Cooperation Council (GCC) member states where precarious employment is prevalent (see Connell and Burgess, 2013; ILO, 2015; PR Newswire, 2015). Finally, the analysis of multifaceted notion of employee voice through the lens of different organisational theories with a focus on socio-cultural, political, religious and economic influences will enrich the literature.

\section{Conclusion}

Our study adds to the knowledge about precarious workers and voice in the context of developing MENA region with a focus on Iran's construction and building materials \& products manufacturing industry. We conclude by highlighting an immature understanding of employee voice by managers and employees. To put it succinctly, the non-existence of voice and participation was obvious. In all cases, employees were found to be notably reticent and seen as acting more as foot-draggers rather than taking charge and speaking up voluntarily to challenge management and enhance self-determination. Specifically, statutory, regulatory and quality compliance as well as HRM policies were seen to function in favour of the management rather than their intended impacts to offer opportunities for employees to voice their concerns and advance their rights.

\section{References}

Ackers P. and Wilkinson A. (eds) (2003). Understanding Work and Employment: Industrial Relations in Transition. Oxford: Oxford University Press.

Adams, R. J. (2005). Efficiency, Equity, and Voice as Moral Imperatives. Employee Responsibilities and Rights Journal, 17(2), pp. 111, 117.

Aguzzoli R. and Geary J. (2014). An 'emerging challenge': the employment practices of a Brazilian multinational company in Canada. Human Relations, 67(5): 587-609.

Allen, M. M. C. (2014). 'Hirschman and Voice'. In A. Wilkinson, J. Donaghey, T. Dundon and R. Freeman (eds.), The Handbook of Research on Employee Voice, Cheltenham and New York: Edward Elgar Press, pp. 36-51.

Aristotle (2011). Politics, Book 8, Part II. Available online: http://classics.mit.edu/Aristotle/politics.8.eight.html (Retrieved 12 May 2017).

Avery, D.R., McKay, P.F., Wilson, D.C., Volpone, S.D. and Killham, E.A., (2011). Does Voice Go Flat? How Tenure Diminished the Impact of Voice. Human Resource Management, 50(1), pp. 147-158.

Bae, J., Chen, S-J., and Rowley, C. (2011). From a paternalistic model towards what? HRM trends in Korea and Taiwan. Personnel Review, 40 (6), pp.700-722. 
Bell, M.P., Ozbiligin, M.F., Beauregard, T.A. and Surgevil, O. (2011).Voice, Silence, and Diversity in 21st Century Organizations: Strategies for inclusion of gay, lesbian, bi-sexual and transgender employees. Human Resource Management, 50, pp. 131-146.

Brewster, C, Croucher, R, Wood, G., and Brookes, M. (2007). Collective and individual voice: Convergence in Europe? International Journal of Human Resource Management, 18(7), pp. 1246-1262.

Broschak, J. P., and Davis-Blake, A. (2006), Mixing Standard Work and Nonstandard Deals: The Consequences of Heterogeneity in Employment Arrangements. Academy of Management Journal, 49, 371-393.

Bruce, K and Nylan, C (2011).Elton Mayo and the Deification of Human Relations', Organization Studies, 32 (3), pp 383-405.

Bryson A (2004). Managerial responsiveness to union and non-union voice in Britain. Industrial Relations, 43 (1), pp. 213-41.

Bryson, A., Gomez, R., Kretschmer, T. and Willman, P. (2007). The Diffusion of Workplace Voice and High-Commitment Human Resource Management Practices in Britain, 1984-1998. Industrial and Corporate Change, 16 (3), pp. 395-426.

Budd, J. W. (2014). The future of employee voice. In A. Wilkinson, J. Donaghey, T. Dundon and R. Freeman (eds.), Handbook of Research on Employee Voice (pp. 477-488). Edward Elgar.

Budd, J. W., Gollan, P. J. and Wilkinson, A. (2010). New Approaches to Employee Voice and Participation in Organizations. Human Relations, 63 (3), pp. 303-310.

Budd, J.W. (2004). Employment with a human face: Balancing efficiency, equity, and voice. Ithaca, NY: Cornell University Press.

Budhwar, P. and Mellahi, K. (2007). Human resource management in the Middle East. International Journal of Human Resource Management, 18 (1), pp. 2-10.

Burgess, J., Connell, J. and Winterton, J. (2013). Vulnerable Workers, Precarious Work and the Role of HRM. International Journal of Human Resource Management, 24 (22), pp. 40834093.

Business Monitor International (2017). Iran infrastructure. Availablehttp://store.bmiresearch.com/iran-infrastructure-report.html (accessed 28 April 2017).

Chen, W., Duan, J. and Tian, X. (2013). Why Do Not Employees Voice: A Chinese Culture Perspective. Advances in Psychological Science, 21(5), pp. 905-913.

Cheng, J. and Kesner, I. (1997). Organizational slack and response to environmental shifts: The impact of resource allocation patterns. Journal of Management, 23: 1-18.

CIA World Factbook (2017). Iran. Available: https://www.cia.gov/library/publications/theworld-factbook/geos/ir.html (accessed 5 April 2017).

CIPD (2010). Voice and engagement: how does collective consultation contribute? 1-21.

Colling T, Gunnigle P, Quintanilla J and Tempel A (2006). Collective representation and participation. In Almond, P. and Ferner, A. (eds) American Multinationals in Europe. Oxford: OUP. 
Corbin, J. and Strauss, A. (2015). Basics of qualitative research: techniques and procedures for developing grounded theory ( $4^{\text {th }}$ edn.). London: Sage.

Donaghey, J., Cullinane, N., Dundon, T. and Wilkinson, A. (2011). Re-conceptualizing employee silence: problems and prognosis. Work, Employment and Society, 25(1), pp. 51-67.

Donnelly, N., Proctor-Thomson, S. and Plimmer, G. (2012). The role of 'voice' in matters of 'choice': flexible work outcomes for women in the New Zealand public services. Journal of Industrial Relations, 54 (2), 182-203.

DuBrin, A. J. (2007). Human Relations Interpersonal Job-Oriented Skills (9 $9^{\text {th }}$ edn.). New Jersey: Pearson Prentice Hall. p. 2.

Dundon, T., Gonzalez-Perez, M.A. and McDonough, T. (2007). Bitten by the Celtic Tiger. Immigrant Workers and Industrial Relations in the New "Glocolized" Ireland. Economic and Industrial Democracy, 28 (4), pp. 501-522.

Dundon, T., Wilkinson, A., Marchington, M. and Ackers, P. (2004). The meanings and purpose of employee voice. International Journal of Human Resource Management, 15(6), pp. 11501171.

Dusek, M. (2015). What next for Iran's economy? World Economic Forum. https://www.weforum.org/agenda/2015/07/what-next-for-irans-economy/ (accessed 1 May 2017).

Eichhorst, W. and Marx, P. (eds) (2015). Non-Standard Employment in Post-Industrial Labour Markets: An Occupational Perspective. Edward Elgar, Cheltenham.

Eisenhardt, K. (1989). Building theories from case study research. Academy of Management Review 14 (4): 532-550.

Eisenhardt, K. M. and Graebner, M. E. (2007). Theory building from case studies: Opportunities and challenges. Academy of Management Journal, 50(1), 25-32.

Encyclopedia Britannica (2017). Iran. Encyclopedia Britannica. https://global.britannica.com/place/Iran (accessed 14 April 2017).

FIDH \& LDDHI (2013). Right to work, labour rights \& trade unions in Iran. http://tbinternet.ohchr.org/Treaties/CESCR/Shared\%20Documents/IRN/INT_CESCR_NGO IRN_13463_E.pdf (accessed 2 March 2017)

Freeman, R. B., and Medoff, J. L. (1984). What do unions do? New York: Basic Books.

Freeman, R.B., Boxall, P. and Haynes, P. (2007). What Workers Say: Employee Voice in the Anglo-American Workplace. Cornell University Press: USA.

Frye, R. N. (2005). Greater Iran: A 20th-century Odyssey. Costa Mesa, CA: Mazda Publishers.

Gomez, R., Bryson, A. and Willman, P. (2010). 'Voice in the wilderness? The shift from union to non-union voice in Britain'. In A. Wilkinson, P. J. Gollan, M. Marchington and D. Lewin (eds.) The Oxford Handbook of Participation in Organizations, Oxford: Oxford University Press.

Harris, L. C. and Ogbonna, E. O. (2002). The unintended consequences of culture interventions: A study of unexpected outcomes. British Journal of Management 13 (1): 31-49.

Hirschman, A. (1970). Exit, Voice, and Loyalty: Responses to Decline in Firms, Organizations, and States. Cambridge, Mass.: Harvard University Press. 
Hofstede, G. (2001). Culture's consequences: Comparing values, behaviours, institutions, and organizations across nations. Thousand Oaks, CA: Sage.

ILO (2005). Economic Security for a Better World. Geneva: International Labour Office. Socio-Economic Security Programme. Second impression.

Javidan, M., \& Dastmalchian, A. (2003). Culture and leadership in Iran: The land of individual achievers, strong family ties, and powerful elite. Academy of Management Executive, 17 (4): 127-142.

Kalleberg, A.L. (2009). Precarious Work, Insecure Workers: Employment Relations in Transition. American Sociological Review, 74 (February): 1-22.

Karimi Moughari, Z. (2007). The Effects of Afghan Immigrants on the Iranian Labour Market. Iranian Economic Review, 13 (20): 57-84.

Kaufman, B. E. and Taras, D. G. (2016). Nonunion Employee Representation: History, Contemporary Practice and Policy. New York: Routledge.

Kochan, T. A. (2012). The American Jobs Crisis and Its Implication for the Future of Employment Policy: A Call for a New Jobs Compact. Industrial and Labor Relations Review, 66(2), pp. 292-314.

Krueger, R. A. and Casey, M. A. (2000). Focus groups: A practical guide for applied research ( $3^{\text {rd }}$ edn.). Thousand Oaks, CA: Sage.

Maslow, A. H. (1943). A Theory of Human Motivation. Psychological Review, 50(4), 370-96.

Mays, W. (1968). Introduction. In Gobar, Philosophic Foundations of Genetic Psychology and Gestalt psychology. Martinus, Nijhoff, The Hague, Netherland.

Mellahi, K., Budhwar, P. S., and Li, B. (2010). A study of the relationship between exit, voice, loyalty and neglect and commitment in India. Human Relations, 63: 349-369.

Menendez, M. G. and Lucio, M. M. (2014). Voice across borders: Comparing and explaining the dynamics of participations in a context of change. In: A. Wilkinson, J. Donaghey, T. Dundon and R. B. Freeman (eds.). The Handbook on Employee Voice. Cheltenham: Edward Elgar; 2014. pp. 381-397.

Miles, M. B. and Huberman, A. M. (1994). Qualitative data analysis. Beverly Hills, California: Sage Publications.

Milliken, F.J., Morrison, E.W. and Hewlin, P.F. (2003). An exploratory study of employee silence: Issues that employees don't communicate upward and why. Journal of Management Studies, 40 (6), pp. 1453-1476.

Morrison, E. W. (2014). Employee voice and silence. Annual Review of Organizational Psychology and Organizational Behavior, 1: 173-197.

Namazie, P. and Tayeb, M. (2006). Human Resource Management in Iran. In P. S. Budhwar, \& K. Mellahi, Managing Human Resources in the Middle East (1st ed., pp. 20-39). New York: Routledge.

Ogbonna, E. and Harris, L. (2006). The dynamics of employee relationships in an ethnically diverse workforce. Human Relations, 59 (3): 379-407.

Perlow, L. A. and Williams, S. (2003). Is silence killing your company? Harvard Business Review, 81 (5): 52-58. 
Pyman, A., Cooper, B., Teicher, J., and Holland, P. (2006). A comparison of the effectiveness of employee voice arrangements in Australia. Industrial Relations Journal, 37: 543-559.

Pyman, A., Gollan, P. J., Wilkinson, A., Xu, C. and Kalfa, S. (2017). Introduction Employee Voice in Emerging Economies: Charting new territory. Advances in Industrial and Labor Relations, 23, pp. ix-xiv., Emerald Group Publishing Limited.

Salehi-Isfahani, H. and Pesaran, M. H. (2009). The Iranian Economy in the Twentieth Century: A Global Perspective, Iranian Studies, 42 (2): 177-211.

Silverman, D. (2011). Interpreting Qualitative Data. London: SAGE Publications.

Souza de, U. (2000). Managing workers in production: Overview of labour in the building industry. Translation of a presentation (TG-007), University of São Paulo.

Standing, G. (2008). Economic insecurity and global casualization. Social Indicators Research, 88 (1), pp. 15-30.

Storey, J. (1992). Developments in the management of human resources: An analytical review. Blackwell, Oxford.

Syed, J. (2014). Diversity management and missing voices. In Wilkinson, A., Donaghey, J., Dundon, T. and Freeman, R. (eds) The Handbook of Research on Employee Voice: Participation and Involvement in the Workplace, London: Elgar Press.

Tayeb, M. (2001). Human resource management in Iran. In Budhwar, P. S. and Debrah, Y. A. (eds.) Human Resource Management in Developing Countries (pp. 121-134). New York: Routledge.

Tayeb, M. H. (1999). Management in Iran. In M. Warner (ed.) Management in emerging countries. London: International Thomson business Press (pp. 316-323).

Taylor, P. and Bain, P. (2005). India calling to the far away towns': the call centre labour process and globalization. Work, Employment \& Society 19(2): 261-282.

Van Wanrooy B., Bewley H., Bryson A., Forth J., Freeth S., Stokes L. and Wood S. (2011). The 2011 Workplace Employment Relations Survey First Findings, pp 1-42.

Vorhauser-Smith, S. (2013). How the Best Places to Work are Nailing Employee Engagement. Forbes. Available at: https://www.forbes.com/sites/sylviavorhausersmith/2013/08/14/howthe-best-places-to-work-are-nailing-employee-engagement/\#3d90886d5cc7 $\quad$ (accessed 28 April 2017).

Wilkinson, A, Gollan, P, Marchington, M and Lewin, D (eds) (2010). The Oxford Handbook of Participation in Organizations, Oxford University Press, Oxford.

Wilkinson, A. and Fay, C. (2011). New times for employee voice? Human Resource Management, 50(1): 65-74.

Wilkinson, A., Donaghey, J., Dundon, T. and Freeman, R. (eds.) (2014). Employee voice: charting new terrain. In Wilkinson, A., Donaghey, J., Dundon, T. and Freeman, R. (eds). The Handbook of Research on Employee Voice: Participation and Involvement in the Workplace (pp. 3-16), London: Edward Elgar Press.

Wilkinson, A., Dundon, T. and Marchington, M. (2013) Employee Involvement and Voice. In S. Bach and M. R. Edwards (eds) Managing Human Resources: Human Resource Management in Transition (pp 268-288). John Wiley \& Sons, Inc., Hoboken, NJ, USA. 
Wilkinson, A., Dundon, T., Marchington, M. and Ackers, P. (2004). The changing patterns of employee voice: case studies from the UK and Republic of Ireland. Journal of Industrial Relations, 46 (3): 298-323.

Wilkinson, A., Gollan, P. J., Marchington, M., \& Lewin, D. (eds) (2010). The Oxford Handbook of Participation in Organizations. New York: Oxford University Press.

Wood and T. Wall, (2007). Work Enrichment and employee voice in human resource Management-Performance Studies. International Journal of Human Resource Management, Vol. 18, No. 7, 2007, pp. 1335-1372.

Wood, G. (2010). Employee Participation in Developing and Emerging Countries. In Wilkinson, A., Gollan, P. J., Lewin, D., Marchington, M. and (eds) The Oxford Handbook of Participation in Organizations (pp. 552-569). Oxford: Oxford University Press.

Wood, G. and Frynas, J. G. (2006). The institutional basis of economic failure: anatomy of the segmented business system. Socio-Economic Review, 4(2):239- 277.

Yin, R. K. (2014). Case study research: Design and methods ( $5^{\text {th }}$ ed.). Newbury Park, CA: Sage Publications. 
Table 1. An overview of Iran's demographic, socio-economic, cultural and political context

\begin{tabular}{|c|c|}
\hline Location & $\begin{array}{l}\text { Middle East, bordering the Gulf of Oman, the Persian Gulf, and the Caspian Sea, between Iraq and Pakistan; Strategic location on the Persian Gulf and Strait of Hormuz } \\
\text { (which are vital maritime pathways for crude oil transport) }\end{array}$ \\
\hline Religious background & Muslim 98\% (Shia Muslim 89\%, Sunni Muslim 9\%); Other 2\% (Zoroastrian, Armani, Christian, Jewish). \\
\hline Population & Population: $80,719,371$ (2 April 2017) (Country comparison to the world: 19 ); $2 / 3$ of population are under the age of 30 \\
\hline Language and dialect spoken & $\begin{array}{l}\text { Persian, Luri, Gilaki, and Mazandarani 58\%; Azeri and other Turkic languages 26\%; Kurdish 9\%; Balochi 1\%; Arabic 1\%; Others including Armenian, Assyrian, Brahui, etc. } \\
5 \%\end{array}$ \\
\hline Education & $\begin{array}{l}\text { Overall rate of } 85 \% \text { literacy; literacy rate for population aged } 15 \text { and above: } 91 \% \text {; Categorised in the "High Human Development" bracket; } \\
\text { Ranked first in scientific growth in the world in } 2011 .\end{array}$ \\
\hline Cultural background & $\begin{array}{l}\text { Part of the South Asian cultural cluster consisting of such countries as India, Thailand, and Malaysia — as opposed to the Arab culture as it is dominated by most of the } \\
\text { Middle Eastern countries; } \\
\text { Iranian culture is class based, traditional and patriarchal. Tradition for most is rooted in religion and class and patriarchy have been constant features of Iranian society since } \\
\text { ancient times. }\end{array}$ \\
\hline Government & $\begin{array}{l}\text { Capital (Tehran); Theocratic republic; religious legal system based on secular and Islamic law. } \\
\text { Chief of state: Supreme Leader (appointed for life by the Assembly of Experts); Head of Government: President; } \\
\text { Cabinet: Council of Ministers selected by the president with legislative approval. } \\
\text { The Executive branch of Government are three oversight bodies: (1) Council of Guardians of the Constitution or Council of Guardians or Guardians Council (Shora-ye } \\
\text { Negban-e Qanon-e Asasi) determines whether proposed legislation is both constitutional and faithful to Islamic law, vets candidates in popular elections for suitability, and } \\
\text { supervises national elections; (2) Assembly of Experts (Majles-e Khoebregan), an elected consultative body of senior clerics constitutionally mandated to select, appoint, } \\
\text { supervise, and dismiss the Supreme Leader; and (3) Expediency Council or the Council for the Discernment of Expediency (Majma-ye- Tashkhis-e -Maslahat-e-Nezam) } \\
\text { resolves legislative issues when the Majles and the Council of Guardians disagree. In } 2005 \text { the Council's powers were expanded to act as a supervisory body for the } \\
\text { government. Elections: president elected by popular vote for a four-year term (eligible for a second term and additional non-consecutive term) }\end{array}$ \\
\hline Economy & $\begin{array}{l}\text { Iran's 20-year economic perspective: promoting a knowledge-based economy; } \\
\text { Economy: a semi-developed transition economy; } \\
\text { Currency: Iranian Rial (IRR); } \\
\text { Ownership: state, cooperative, private; } \\
\text { Energy superpower (founding member of OPEC); ranked } 39^{\text {th }} \text { in a list of industrialised nations; unemployment rate: approximately } 10 \% \text {; inflation rate: approximately } 15 \% \text {; } \\
\text { The 20-Year Vision Plan (since 2002): to promote the position of the Islamic Republic of Iran in national, regional and international levels in which Iran becomes a } \\
\text { developed country in twenty years, with the first economic, scientific and technical stand in the region. } \\
\text { Compliance with human rights at work. } \\
\text { Convention against the Worst Forms of Child Labour. } \\
\text { In theory labour law and related legislations in Iran lay a heavy focus on prompting Equality of Opportunity in Employment for all employees from any background and } \\
\text { eliminating discrimination on any ground (e.g. gender, religion, ethnic background). For example, based upon the domestic legal framework (and consistent with the } \\
\text { international legal framework), workers have right to form (independent) labour unions, to strike, to work in favourable working conditions. However, the practice falls short } \\
\text { of standards required under International Committee on Economic, Social and Cultural Rights (ICESCR) (see for further details, FIDH/LDDHI, 2013). }\end{array}$ \\
\hline
\end{tabular}

Source: CIA World Factbook (2017); Javidan \& Dastmalchian (2003); Soltani (2010); Soltani et al. (2012, 2014); Price (2001); Frye (2005); FIDH \&LDDHI (2013). 
Table 2. Sampled company profile

\begin{tabular}{|c|c|c|c|c|c|c|c|c|c|}
\hline Company type & $\begin{array}{l}\text { Scope of } \\
\text { operations }\end{array}$ & $\begin{array}{l}\text { Main product \& service } \\
\text { offerings }\end{array}$ & $\begin{array}{l}\text { Company } \\
\text { ownership }\end{array}$ & $\begin{array}{l}\text { Decade of } \\
\text { founding }\end{array}$ & Location & $\begin{array}{l}\text { Size } \\
\text { (varies } \\
\text { from site } \\
\text { to site)* }\end{array}$ & $\begin{array}{l}\text { Intensity of } \\
\text { competition }\end{array}$ & $\begin{array}{l}\text { Espoused motivation for } \\
\text { employee voice }\end{array}$ & $\begin{array}{l}\text { Approach to } \\
\text { the adoption } \\
\text { and diffusion of } \\
\text { employee voice }\end{array}$ \\
\hline Construction and building & $\begin{array}{l}\text { Domestic and } \\
\text { regional (with a } \\
\text { focus on MENA } \\
\& \text { developing } \\
\text { countries) }\end{array}$ & $\begin{array}{l}\text { Road, tunnel, bridge, } \\
\text { installations, commercial } \\
\text { lighting projects, } \\
\text { construction services such } \\
\text { as project management }\end{array}$ & private & Early 1980s & $\begin{array}{l}\text { Head office: } \\
\text { Tehran; multiple } \\
\text { local and regional } \\
\text { offices; multi-site } \\
\text { facilities across the } \\
\text { country }\end{array}$ & Large & High & $\begin{array}{l}\text { Compliance with ISO } \\
\text { standards requirements and } \\
\text { certification; Improving } \\
\text { business relationship with the } \\
\text { Ministry of Industries and } \\
\text { Mines to receive formal } \\
\text { invitations to bid on profitable } \\
\text { public sector projects }\end{array}$ & $\begin{array}{l}\text { Imperative and } \\
\text { top-down } \\
\text { characteristics }\end{array}$ \\
\hline Construction and mining & $\begin{array}{l}\text { Domestic and } \\
\text { international (e.g. } \\
\text { China) }\end{array}$ & $\begin{array}{l}\text { Residential, commercial } \\
\text { and cultural buildings, } \\
\text { export of raw minerals/ore }\end{array}$ & private & Mid 1980s & $\begin{array}{l}\text { Head office: } \\
\text { Tehran; multiple } \\
\text { local and } \\
\text { international } \\
\text { offices; multi-site } \\
\text { facilities across the } \\
\text { country }\end{array}$ & large & High & $\begin{array}{l}\text { A desire to appear legitimate to } \\
\text { administrative authorities in } \\
\text { particular with regard to } \\
\text { winning government-funded } \\
\text { construction projects; } \\
\text { marketing considerations to } \\
\text { recruit workers for some of } \\
\text { most dangerous occupations. }\end{array}$ & $\begin{array}{l}\text { Hierarchical and } \\
\text { top down } \\
\text { decision making }\end{array}$ \\
\hline $\begin{array}{l}\text { Construction, mining and } \\
\text { supplier }\end{array}$ & $\begin{array}{l}\text { Domestic and } \\
\text { international (e.g. } \\
\text { China, Malaysia) }\end{array}$ & $\begin{array}{l}\text { Different types of stones } \\
\text { (e.g. ornamental, } \\
\text { constructional) }\end{array}$ & Private & Late 1970s & $\begin{array}{l}\text { Head office: } \\
\text { Tehran; multiple } \\
\text { local and } \\
\text { international } \\
\text { offices; multi-site } \\
\text { facilities across the } \\
\text { country }\end{array}$ & large & High & $\begin{array}{l}\text { To cope with competitive } \\
\text { pressure and increase export } \\
\text { propensity; } \\
\text { Compliance to the COFRAC } \\
\text { accreditations requirements }\end{array}$ & $\begin{array}{l}\text { Profit-centric } \\
\text { approach from } \\
\text { the top }\end{array}$ \\
\hline $\begin{array}{l}\text { Manufacturer and supplier } \\
\text { of construction materials }\end{array}$ & $\begin{array}{l}\text { Domestic and } \\
\text { regional (e.g. } \\
\text { UAE, Lebanon) }\end{array}$ & $\begin{array}{l}\text { Various types of brick (e.g. } \\
\text { press, surface, perforated) } \\
\text { and block (e.g. ceiling, } \\
\text { partition) }\end{array}$ & Private & Early 1970s & $\begin{array}{l}\text { Head office: } \\
\text { Tehran; multiple } \\
\text { local and regional } \\
\text { offices; multi-site } \\
\text { facilities across the } \\
\text { country } \\
\end{array}$ & large & High & $\begin{array}{l}\text { Quality management } \\
\text { accreditation; a platform to } \\
\text { attract and retain business } \\
\text { operations with the government } \\
\text { as a major customer for } \\
\text { construction materials. }\end{array}$ & $\begin{array}{l}\text { Centralized and } \\
\text { top-down policy } \\
\text { making }\end{array}$ \\
\hline $\begin{array}{l}\text { Manufacturer and supplier } \\
\text { of construction materials }\end{array}$ & $\begin{array}{l}\text { Domestic and } \\
\text { regional (e.g. } \\
\text { most of MENA } \\
\text { countries) }\end{array}$ & $\begin{array}{l}\text { Ceramic tile adhesive, non- } \\
\text { shrinking grout materials, } \\
\text { tile grout, self- } \\
\text { evelling cement/mortar }\end{array}$ & Private & Early 1980s & $\begin{array}{l}\text { Head office: } \\
\text { Tehran; multiple } \\
\text { local and regional } \\
\text { offices; multi-site } \\
\text { facilities across the } \\
\text { country }\end{array}$ & large & High & $\begin{array}{l}\text { To secure compliance with } \\
\text { occupational safety \& health } \\
\text { regulations and prevention of } \\
\text { risk arising from non- } \\
\text { compliance; to counteract the } \\
\text { notion of vulnerable } \\
\text { employment }\end{array}$ & $\begin{array}{l}\text { Top-down } \\
\text { business/econo } \\
\text { mic approach }\end{array}$ \\
\hline $\begin{array}{l}\text { Manufacturer and supplier } \\
\text { of construction materials }\end{array}$ & $\begin{array}{l}\text { Domestic and } \\
\text { regional (All } \\
\text { GCC and MENA } \\
\text { countries) }\end{array}$ & $\begin{array}{l}\text { Different types of tile (e.g. } \\
\text { ceramic, wall and floor) }\end{array}$ & Private & Mid 1970s & $\begin{array}{l}\text { Head office: } \\
\text { Tehran; multiple } \\
\text { local and regional } \\
\text { offices; multi-site } \\
\text { facilities across the } \\
\text { country } \\
\end{array}$ & large & High & $\begin{array}{l}\text { The need for high level of } \\
\text { individual and organizational } \\
\text { productivity and performance; } \\
\text { enhancing business reputation } \\
\text { of the high hazard industry of } \\
\text { construction in the country. } \\
\end{array}$ & $\begin{array}{l}\text { Centralized } \\
\text { approach } \\
\text { supported by } \\
\text { external } \\
\text { consulting firms }\end{array}$ \\
\hline
\end{tabular}




\begin{tabular}{|c|c|c|c|c|c|c|c|c|c|}
\hline Cases & $\begin{array}{l}\text { Number of } \\
\text { interviewees (n): } \\
\text { Manager [M), } \\
\text { Employee [E] }\end{array}$ & $\begin{array}{l}\text { Hierarchical } \\
\text { responsibility: senior } \\
(\text { S), middle (M), first- } \\
\text { line (F) shop floor } \\
\text { worker (SW) }\end{array}$ & $\begin{array}{l}\text { Functional } \\
\text { responsibility: Finance } \\
\text {, Design / Engineering, } \\
\text { Human resource } \\
\text { Operations/Project }\end{array}$ & $\begin{array}{l}\text { Length of service in the } \\
\text { current organization (in } \\
\text { years): Minimum (Min), } \\
\text { Maximum (Max) }\end{array}$ & $\begin{array}{l}\text { Gender: } \\
\text { Male (M), } \\
\text { Female (F) }\end{array}$ & $\begin{array}{l}\text { Average } \\
\text { length of } \\
\text { prior work } \\
\text { experience } \\
\text { (in } \\
\text { years):Manag } \\
\text { ers (M) } \\
\text { Employees } \\
\text { (E) }\end{array}$ & $\begin{array}{l}\text { *Education: High } \\
\text { School Diploma } \\
\text { (HSD), Vocational } \\
\text { School (VS), } \\
\text { University Degree } \\
\text { (UD) }\end{array}$ & $\begin{array}{l}\text { Average } \\
\text { age: } \\
\text { Managers } \\
\text { (M) } \\
\text { Workers } \\
\text { (W) }\end{array}$ & $\begin{array}{l}* * \text { Number of } \\
\text { ex-post } \\
\text { interviews: } \\
\text { Manager [M]; } \\
\text { Employee [E] }\end{array}$ \\
\hline $\begin{array}{l}\text { Construction and } \\
\text { building }\end{array}$ & $\begin{array}{l}\mathrm{n}=14 \\
5 \mathrm{M} 9 \mathrm{E}\end{array}$ & $1 \mathrm{~S} 2 \mathrm{M} \quad 2 \mathrm{~F} 9 \mathrm{SW}$ & $\begin{array}{l}\text { Representing all } \\
\text { functional areas }\end{array}$ & 3 Min, 8 Max & $13 \mathrm{M} 1 \mathrm{~F}$ & $11 \mathrm{M}, 12.5 \mathrm{E}$ & $9 \mathrm{HSD}, 2 \mathrm{VS}, 3 \mathrm{UD}$ & $\begin{array}{l}34.5 \mathrm{M} \\
37.5 \mathrm{~W}\end{array}$ & $\begin{array}{l}\mathrm{n}=3 \\
1 \mathrm{M}, 2 \mathrm{E}\end{array}$ \\
\hline $\begin{array}{l}\text { Construction and } \\
\text { mining }\end{array}$ & $\begin{array}{l}n=16 \\
5 \mathrm{M} 11 \mathrm{E}\end{array}$ & $1 \mathrm{~S} 2 \mathrm{M} \quad 2 \mathrm{~F} 11 \mathrm{SW}$ & $\begin{array}{l}\text { Representing all } \\
\text { functional areas }\end{array}$ & $6 \operatorname{Min}, 11 \mathrm{Max}$ & $14 \mathrm{M} 2 \mathrm{~F}$ & $7 \mathrm{M}, 12 \mathrm{E}$ & $11 \mathrm{HSD}, 0 \mathrm{VS}, 5 \mathrm{UD}$ & $\begin{array}{l}41 \mathrm{M} \\
39.5 \mathrm{~W}\end{array}$ & $\begin{array}{l}n=3 \\
1 \mathrm{M}, 2 \mathrm{E}\end{array}$ \\
\hline $\begin{array}{l}\text { Construction, } \\
\text { mining and } \\
\text { supplier }\end{array}$ & $\begin{array}{l}n=17 \\
6 \mathrm{M} \quad 11 \mathrm{E}\end{array}$ & $2 \mathrm{~S} 2 \mathrm{M} \quad 2 \mathrm{~F} \quad 11 \mathrm{SW}$ & $\begin{array}{l}\text { Representing all } \\
\text { functional areas }\end{array}$ & 3Min, 8 Max & $15 \mathrm{M} 2 \mathrm{~F}$ & $7.5 \mathrm{M}, 10 \mathrm{E}$ & $10 \mathrm{HSD}, 2 \mathrm{VS}, 5 \mathrm{UD}$ & $\begin{array}{l}37.5 \mathrm{M} \\
43.5 \mathrm{~W}\end{array}$ & $\begin{array}{l}\mathrm{n}=3 \\
1 \mathrm{M}, 2 \mathrm{E}\end{array}$ \\
\hline $\begin{array}{l}\text { Manufacturer } \\
\text { and supplier of } \\
\text { construction } \\
\text { material }\end{array}$ & $\begin{array}{l}n=15 \\
5 M \quad 10 E\end{array}$ & $1 \mathrm{~S} 2 \mathrm{M} \quad 2 \mathrm{~F} \quad 10 \mathrm{SW}$ & $\begin{array}{l}\text { Representing all } \\
\text { functional areas }\end{array}$ & 6 Min, 9Max & $12 \mathrm{M} 3 \mathrm{~F}$ & $8.5 \mathrm{M}, 13.5 \mathrm{E}$ & $8 \mathrm{HSD}, 2 \mathrm{VS}, 5 \mathrm{UD}$ & $\begin{array}{l}46.5 \mathrm{M} \\
42.5 \mathrm{~W}\end{array}$ & $\begin{array}{l}\mathrm{n}=3 \\
1 \mathrm{M}, 2 \mathrm{E}\end{array}$ \\
\hline $\begin{array}{l}\text { Manufacturer } \\
\text { and supplier of } \\
\text { construction } \\
\text { materials }\end{array}$ & $\begin{array}{l}n=16 \\
4 M \quad 12 E\end{array}$ & $1 \mathrm{~S} 1 \mathrm{M} \quad 2 \mathrm{~F} \quad 12 \mathrm{SW}$ & $\begin{array}{l}\text { Representing all } \\
\text { functional areas }\end{array}$ & 7Min, 11Max & $13 \mathrm{M} 3 \mathrm{~F}$ & $8 \mathrm{M}, 10.5 \mathrm{E}$ & $9 \mathrm{HSD}, 4 \mathrm{VS}, 3 \mathrm{UD}$ & $\begin{array}{l}41.5 \mathrm{M} \\
47.5 \mathrm{~W}\end{array}$ & $\begin{array}{l}\mathrm{n}=3 \\
1 \mathrm{M}, 2 \mathrm{E}\end{array}$ \\
\hline $\begin{array}{l}\text { Manufacturer } \\
\text { and supplier of } \\
\text { construction } \\
\text { materials }\end{array}$ & $\begin{array}{l}\mathrm{n}=14 \\
5 \mathrm{M} 9 \mathrm{E}\end{array}$ & $1 \mathrm{~S} 2 \mathrm{M} \quad 2 \mathrm{~F} 9 \mathrm{SW}$ & $\begin{array}{l}\text { Representing all } \\
\text { functional areas }\end{array}$ & 5Min, $11 \mathrm{Max}$ & $12 \mathrm{M} 2 \mathrm{~F}$ & $7.5 \mathrm{M}, \mathrm{E} 1.5$ & $3 \mathrm{HSD}, 2 \mathrm{VS}, 5 \mathrm{UD}$ & $\begin{array}{l}38.5 \mathrm{M} \\
36.5 \mathrm{~W}\end{array}$ & $\begin{array}{l}\mathrm{n}=3 \\
1 \mathrm{M}, 2 \mathrm{E}\end{array}$ \\
\hline
\end{tabular}

*Note: A majority of managerial interviewees had a university degree and a majority of non-managerial informants had a high school diploma.

**Note: Number of interviewees in each case is inclusive of ex-post interviews. 


\begin{tabular}{|c|c|c|c|c|c|c|c|c|}
\hline $\begin{array}{l}\text { Focus group } \\
\text { interviews }\end{array}$ & $\begin{array}{l}\text { Number of } \\
\text { participants } \\
\text { (n) }\end{array}$ & $\begin{array}{l}\text { Hierarchical } \\
\text { responsibility: senior(S), } \\
\text { middle }(M) \text {, first-line }(F) \\
\text { shop floor worker }(\mathrm{SW})\end{array}$ & $\begin{array}{l}\text { Functional responsibility: } \\
\text { Finance, Design / } \\
\text { Engineering, Human resource, } \\
\text { Operations/Project }\end{array}$ & $\begin{array}{l}\text { Length of service in the } \\
\text { current organization (in } \\
\text { years): Minimum (Min), } \\
\text { Maximum (Max) }\end{array}$ & $\begin{array}{l}\text { Gender: } \\
\text { Male (M), } \\
\text { Female (F) }\end{array}$ & $\begin{array}{l}\text { Average length of } \\
\text { prior work } \\
\text { experience (in } \\
\text { years): Managers } \\
\text { (M) Employees } \\
\text { (E) }\end{array}$ & $\begin{array}{l}\text { Education: High School } \\
\text { Diploma (HSD), } \\
\text { Vocational School (VS), } \\
\text { University Degree (UD) }\end{array}$ & $\begin{array}{l}\text { Average age: } \\
\text { Managers (M) } \\
\text { Workers (W) }\end{array}$ \\
\hline $\begin{array}{l}\text { Construction } \\
\text { and building }\end{array}$ & $\begin{array}{l}n=12 \\
7 \mathrm{M} 5 \mathrm{E}\end{array}$ & $2 \mathrm{~S}, 2 \mathrm{M}, 3 \mathrm{~F}, 5 \mathrm{SW}$ & Representing all functional areas & 4 Min 9 Max & $9 \mathrm{M} \quad 3 \mathrm{~F}$ & $7.5 \mathrm{M} 10 \mathrm{E}$ & $3 \mathrm{HSD}, 6 \mathrm{VS}, 3 \mathrm{UD}$ & $37 \mathrm{M} 41.5 \mathrm{~W}$ \\
\hline $\begin{array}{l}\text { Construction } \\
\text { and mining }\end{array}$ & $\begin{array}{l}n=14 \\
8 \mathrm{M} 6 \mathrm{E}\end{array}$ & $1 \mathrm{~S}, 3 \mathrm{M}, 4 \mathrm{~F}, 6 \mathrm{SW}$ & Representing all functional areas & 5 Min to 10 Max & $11 \mathrm{M} \quad 3 \mathrm{~F}$ & $9 \mathrm{M} 7.5 \mathrm{E}$ & $6 \mathrm{HSD}, 4 \mathrm{VS}, 4 \mathrm{UD}$ & $39.5 \mathrm{M} 39 \mathrm{~W}$ \\
\hline $\begin{array}{l}\text { Construction, } \\
\text { mining and } \\
\text { supplier }\end{array}$ & $\begin{array}{l}n=11 \\
6 \mathrm{M} 5 \mathrm{E}\end{array}$ & $2 \mathrm{~S}, 2 \mathrm{M}, 2 \mathrm{~F}, 5 \mathrm{SW}$ & Representing all functional areas & 4 Min to 8 Max & $7 \mathrm{M} \quad 4 \mathrm{~F}$ & $6.6 \mathrm{M} 8.5 \mathrm{E}$ & $5 \mathrm{HSD}, 3 \mathrm{VS}, 3 \mathrm{UD}$ & $42 \mathrm{M} 40 \mathrm{~W}$ \\
\hline $\begin{array}{l}\text { Manufacturer } \\
\text { and supplier of } \\
\text { construction } \\
\text { material }\end{array}$ & $\begin{array}{l}n=10 \\
6 \mathrm{M} 4 \mathrm{E}\end{array}$ & $1 \mathrm{~S}, 3 \mathrm{M}, 2 \mathrm{~F}, 4 \mathrm{SW}$ & Representing all functional areas & 7 Min to 13 Max & $6 \mathrm{M} \quad 4 \mathrm{~F}$ & $5.5 \mathrm{M} \quad 10.5 \mathrm{E}$ & $2 \mathrm{HSD}, 4 \mathrm{VS}, 4 \mathrm{UD}$ & $39 \mathrm{M} 46 \mathrm{~W}$ \\
\hline $\begin{array}{l}\text { Manufacturer } \\
\text { and supplier of } \\
\text { construction } \\
\text { materials }\end{array}$ & $\begin{array}{l}n=13 \\
8 \mathrm{M} \mathrm{5E}\end{array}$ & $2 \mathrm{~S}, 2 \mathrm{M}, 4 \mathrm{~F}, 5 \mathrm{SW}$ & Representing all functional areas & 6 Min to $12 \operatorname{Max}$ & $9 \mathrm{M} \quad 4 \mathrm{~F}$ & $7.5 \mathrm{M} 5.5 \mathrm{E}$ & $2 \mathrm{HSD}, 6 \mathrm{VS}, 5 \mathrm{UD}$ & $44.5 \mathrm{M} 36.5 \mathrm{~W}$ \\
\hline $\begin{array}{l}\text { Manufacturer } \\
\text { and supplier of } \\
\text { construction } \\
\text { materials }\end{array}$ & $\begin{array}{l}n=12 \\
5 \mathrm{M} 7 \mathrm{E}\end{array}$ & $1 \mathrm{~S}, 2 \mathrm{M}, 2 \mathrm{~F}, 7 \mathrm{SW}$ & Representing all functional areas & 5 Min to 14 Max & $8 \mathrm{M} \quad 4 \mathrm{~F}$ & $8 \mathrm{M} \quad 8.5 \mathrm{E}$ & $2 \mathrm{HSD}, 3 \mathrm{VS}, 7 \mathrm{UD}$ & $41.5 \mathrm{M} \quad 43 \mathrm{~W}$ \\
\hline
\end{tabular}


Table 5. Supporting evidence for themes in various sources of data (findings)

\begin{tabular}{|c|c|}
\hline $\begin{array}{l}\text { The nature and } \\
\text { scope of } \\
\text { employee voice }\end{array}$ & Individual, face-to-face interviews \\
\hline $\begin{array}{l}\text { Understand } \\
\text { and awareness } \\
\text { of employee } \\
\text { voice: } \\
\text { Uncertainty } \\
\text { and confusion }\end{array}$ & $\begin{array}{l}\text { We always talk to our workers to make sure that they are aware of our expectations and their } \\
\text { responsibilities. They can also ask any work-related questions that they might have at any } \\
\text { time. [Site Construction Manager] } \\
\text { Workers will only be paid if they finish the assigned tasks as required. They are well aware } \\
\text { of it and we often remind them to ask if they need further instructions to complete their daily } \\
\text { tasks to our satisfaction. [Electrical Construction Supervisor] } \\
\text { If I rate a worker's daily performance as unsatisfactory, the company reduces his/her wage or } \\
\text { increases the worker's work hours. As a result, we frequently talk to workers about their } \\
\text { responsibilities and progress. [Head, Building Materials \& Products Supervision Unit] } \\
\text { We are happy to listen to issues that concern our workers and we encourage them to tell us } \\
\text { about their problems. [Assistant Manager, Building Materials \& Products Manufacturer] } \\
\text { We can seek our supervisor's views on things that we do not know at work. Because if } \\
\text { something goes wrong we will be blamed for poor performance. But we cannot ask too much } \\
\text { simply because they might think that we lack knowledge and skills. [Construction Worker] } \\
\text { We never want to hear the words 'you're fired'. We also know that it is unsafe to admit and } \\
\text { report on errors or failure at work. So we are encouraged to ask for further instructions and } \\
\text { guidance and we all must follow them to protect ourselves against unfair dismissal and pay } \\
\text { cut. We do not say or even we are not welcomed to say more than what we need to do our } \\
\text { jobs. [Forklift Operator, Building Materials \& Products Manufacturer] }\end{array}$ \\
\hline $\begin{array}{l}\begin{array}{l}\text { Dimensions of } \\
\text { employee } \\
\text { voice: }\end{array} \\
\text { Statutory and } \\
\text { regulatory } \\
\text { requirements }\end{array}$ & $\begin{array}{l}\text { It is not really up to the management team to decide on employee voice and participation at } \\
\text { work. It is more to do with compliance with both labour law and adopted organisation-wide } \\
\text { continuous improvement programmes such as ISO to involve employees in the } \\
\text { organisation's affairs. [Senior Development Project Manager] } \\
\text { We have achieved ISO } 9001 \text { Certification partially because we have made our workers } \\
\text { aware of our expectations as well as their own areas of responsibility. We prepared a } \\
\text { workbook for our workforce that explains their rights and responsibilities on the job. } \\
\text { [Construction Quality Control Manager] } \\
\text { Workplace quality and safety standards and regulations determine the nature and scope of } \\
\text { employee voice and participation. So we are all well aware of the law as well as }\end{array}$ \\
\hline
\end{tabular}

Archival data/company

policies/company records/employee

records

Press report publicizing the company's

ISO certification as a sign of

management willingness for gaining

employee buy-in in organisational

affairs that affect their work.

A part from the overbroad reference to employee rights in the employee

handbook, there was no explicit or

implicit reference to employee voice

and participation.

The equal opportunity policy of the case organisations was limited to some passages reproduced from the labour law (e.g. right to equality and freedoms for all without distinction as to religion, language, ethnicity). In fact, the equal opportunity policy was viewed as

'faddish window dressing' by a majority of workers as it was seen to lower basic employee rights and expectations and demotivate employees to voice their concerns.

\section{An excerpt from employee handbook} hat workers are not entitled to form independent unions.

A report published by the Labour Inspection Office that instructer construction contractors and employers to observe worker basic rights and improve their terms of employment within the limit of the law.
Informal discussion

\section{Managers viewed the} rights to job safety and basic wage contained in the employee handbook as evidence of employee engagement

Informal discussions with employees highlighted the absence of organised, voice-focused activities in the organisation.

Employees did no comprehend voice as an effective tool and did not understand many of their basic rights.

\section{Evidence of lots of yelling} and accusation of workers by the supervisory level managers.

Workers highlighted the importance of maintaining a good working relationship with their

boss, silence and blind obedience to ensure
Focus group meetings

\section{Employees talked about the}

communication of statutory

requirements and ISO/Quality/health $\&$ safety from the top as the only information that they had about their work and responsibilities.

Employees viewed voice and participation as a very insignificant issue in their daily work.

Evidence that the company policies are strict and inflexible and that it was rather difficult to change policies once they had been implemented.

Data from focus group discussions with both workers and supervisory level managers pointed to a heightened consciousness of the importance of voice practices as an area for concern

\section{Managers pay more regards to}

procedures outlined in the labour law and industry-specific quality and safety standards than their own initiatives to promote voice an partnership. 


\begin{tabular}{|c|c|c|c|c|}
\hline & $\begin{array}{l}\text { consequences for violating the labour law in particular with regard to collective bargaining } \\
\text { and negotiations. [Site Safety and Health Officer] } \\
\text { The law defines our relationship with the workforce and we must ensure that the law and } \\
\text { related internal policies are enforced. This means, we have more concerns over compliance } \\
\text { with the law and regulations than workers' own issues and problems. This is what we are } \\
\text { responsible for. To be frank, I can say for sure that the law itself limits our willingness to } \\
\text { adopt an employee voice and participation perspective. [Production Manager, Building } \\
\text { Materials \& products Manufacturer] } \\
\text { All company policies remind us of severe consequences of non-compliance with mandatory } \\
\text { industry standards or non-compliance with other regulatory bodies. So what is the point to } \\
\text { voice our complaints and concerns. If we do, they blame us for things that we have no } \\
\text { control over. [Concrete Labourer] } \\
\text { All we do is to follow rules or obey orders. Because we are so worried and insecure about } \\
\text { our contract. We do not really think more than compliance with rules and taking orders. } \\
\text { Simply, we are unable to search for meaning in our work because we do not have the } \\
\text { opportunity to make suggestions in an honest way. They know that they do not receive } \\
\text { honest feedback from us. We also know that they do not seek our views to help us with our } \\
\text { work and life. [Insulation Worker] } \\
\text { Our company conducts employee survey on a bi-annual basis. We know that they do this } \\
\text { because they want to comply with the requirements of ISO/quality and safety standards. But } \\
\text { the point is that they never share the survey results with us. In fact, many of my co-workers } \\
\text { do not take part in the survey. Those who do, they do not provide truthful responses as they } \\
\text { fear of retaliation from management. [Store Keeper, Building Materials \& Products } \\
\text { Manufacturer] }\end{array}$ & $\begin{array}{l}\text { Excerpts from company's quarterly } \\
\text { newsletters and weekly briefing } \\
\text { meetings required and frequently } \\
\text { reminded employees "to obey rules and } \\
\text { follow procedures" and warned them of } \\
\text { "consequences of a code of conduct } \\
\text { violation". } \\
\text { Excerpts from ISO } 9001 \text { document } \\
\text { (internal communication requirements) } \\
\text { was communicated to all employees } \\
\text { through company newspaper, requiring } \\
\text { them to only report work-related issues } \\
\text { to their line managers and that they } \\
\text { should keep records of any incidents for } \\
\text { the attention of the line manager. }\end{array}$ & $\begin{array}{l}\text { continuity of their } \\
\text { employment contract. } \\
\text { Informal discussion with } \\
\text { employees stressed the } \\
\text { importance of silence and } \\
\text { withholding information } \\
\text { for fear of retaliation and } \\
\text { job loss. } \\
\text { "We do not want to get } \\
\text { more warning notices for } \\
\text { claiming our basic rights. } \\
\text { We keep quiet and in } \\
\text { exchange we keep our } \\
\text { job". [Construction } \\
\text { Worker] }\end{array}$ & $\begin{array}{l}\text { Evidence that employees have to } \\
\text { remain silent as speaking up could be } \\
\text { interpreted as non-compliance } \\
\text { followed by pay cut and dismissal. }\end{array}$ \\
\hline $\begin{array}{l}\begin{array}{l}\text { Manifestation } \\
\text { of employee } \\
\text { voice: }\end{array} \\
\text { The role and } \\
\text { influence of } \\
\text { hierarchy/status }\end{array}$ & $\begin{array}{l}\text { Construction work is a very repetitive type of activity. We do not expect creative inputs from } \\
\text { the workers. All we need to do is to formulate policies and closely supervise and monitor the } \\
\text { workplace conditions and people. All they need to do is to abide by workplace regulations } \\
\text { and standards under ISO quality management system. [Safety Manager] } \\
\text { Construction sector by nature is a very high-risk sector. I mean poor working conditions, } \\
\text { long work hours, and exposure to safety hazards could all force employees to go on strike to } \\
\text { protest against their poor working conditions. If we adopt an open door policy for workers to } \\
\text { say whatever they want then we have to pay the price. It puts our own interests at risk. So we } \\
\text { have to act in authoritarian and punitive ways. [Construction Site Manager] } \\
\text { My understanding is that they do not see much value in our inputs. Because we are } \\
\text { struggling to fulfil our basic needs such as food and shelter. So they do not expect us to say }\end{array}$ & $\begin{array}{l}\text { HR survey that points to the need to } \\
\text { improve company's health \& safety } \\
\text { through creating a more engaged } \\
\text { workforce as well as improving } \\
\text { working and living conditions of all } \\
\text { workers. } \\
\text { Various press reports on unsecure jobs, } \\
\text { unpaid wages and unsafe working } \\
\text { conditions as the main features of } \\
\text { employment in construction sector. }\end{array}$ & $\begin{array}{l}\text { The importance of } \\
\text { hierarchy was confirmed } \\
\text { in meeting with } \\
\text { employees. } \\
\text { Supervisors were reported } \\
\text { to yell at workers and } \\
\text { workers had to answer } \\
\text { more questions in case } \\
\text { they made suggestions for } \\
\text { further improvement or } \\
\text { reported an error. }\end{array}$ & $\begin{array}{l}\text { Evidence that workers must have } \\
\text { blind faith in high authority and are } \\
\text { expected to be rule-follower and } \\
\text { avoid breaking rules. } \\
\text { Strong evidence of mismanagement } \\
\text { and micro management. Managers } \\
\text { dictated performance criteria and } \\
\text { goals. } \\
\text { Managers were viewed as being too } \\
\text { hands-on. }\end{array}$ \\
\hline
\end{tabular}


or do more than what we need to survive. We are also not motivated to ask for more say in organisational affairs but to fulfil our basic needs. [Crane Operator]

None of us works here to satisfy all our needs as human beings. We simply work hard to survive and support our families. They tell us what to do and how to accomplish a task and what the consequences would be if we fail to do so. We do not have any reasons for hard work but to fulfil our basic needs of food and shelter. [Iron Worker]
Newspapers that point to the cheap and unskilled foreign workers as the main

reasons for their employment an

discriminatory practices against them.

Photographs show desperate conditions

endured by construction workers.

Newspapers that highlights chronic violations of unskilled workers' basic

rights
Employees highlighted

the hierarchy and

obedience to secure their jobs.

Informal discussion with workers confirmed that they were not authorised to meet the labour inspectors individually during their visits. Only those workers who were authorised by the management could hold a group discussion with the labour inspectors.
Employees viewed ISO and regulatory requirements as drivers for the existing tight-meshed contro system at the workplace.

Tight control and fear of making workers' ability to exercise

initiatives in response to workplace problems.

Strict adherence to regulatory requirements (for example

requirements (for example
preventing labor law violation and

penalties) and ISO standards coupled

with adopting a cost minimization

approach through employment of

cheap labor were reported by

supervisory level managers to justify

the tight control system in the case organizations. 